\title{
Pharmacological Modulation and (Patho)Physiological Roles of TRPM4 Channel-Part 1: Modulation of TRPM4
}

\author{
Zsigmond Máté Kovács ${ }^{1,2}$, Csaba Dienes ${ }^{1,2}$, Tamás Hézső ${ }^{1,2}$, János Almássy ${ }^{1}$, János Magyar ${ }^{1,3}$, Tamás Bányász ${ }^{1}$, \\ Péter P. Nánási ${ }^{1,4}$, Balázs Horváth ${ }^{1,5}$ [i] and Norbert Szentandrássy 1,6,*
}

1 Department of Physiology, Faculty of Medicine, University of Debrecen, 4032 Debrecen, Hungary; kovacs.zsigmond@med.unideb.hu (Z.M.K.); dienes.csaba@med.unideb.hu (C.D.); hezso.tamas@med.unideb.hu (T.H.); almassy.janos@med.unideb.hu (J.A.); magyar.janos@med.unideb.hu (J.M.); banyasz.tamas@med.unideb.hu (T.B.); nanasi.peter@med.unideb.hu (P.P.N.); horvath.balazs@med.unideb.hu (B.H.)

2 Doctoral School of Molecular Medicine, University of Debrecen, 4032 Debrecen, Hungary

3 Division of Sport Physiology, Department of Physiology, Faculty of Medicine, University of Debrecen, 4032 Debrecen, Hungary

4 Department of Dental Physiology and Pharmacology, Faculty of Dentistry, University of Debrecen, 4032 Debrecen, Hungary

5 Faculty of Pharmacy, University of Debrecen, 4032 Debrecen, Hungary

6 Department of Basic Medical Sciences, Faculty of Dentistry, University of Debrecen, 4032 Debrecen, Hungary

* Correspondence: szentandrassy.norbert@med.unideb.hu

Citation: Kovács, Z.M.; Dienes, C.; Hézső, T.; Almássy, J.; Magyar, J.;

Bányász, T.; Nánási, P.P.; Horváth, B.; Szentandrássy, N. Pharmacological Modulation and (Patho)Physiological Roles of TRPM4 Channel-Part 1 :

Modulation of TRPM4.

Pharmaceuticals 2022, 15, 81 .

https://doi.org/10.3390/

ph15010081

Academic Editor: Anna

Stary-Weinzinger

Received: 8 December 2021

Accepted: 6 January 2022

Published: 10 January 2022

Publisher's Note: MDPI stays neutral with regard to jurisdictional claims in published maps and institutional affiliations.

Copyright: (C) 2022 by the authors. Licensee MDPI, Basel, Switzerland. This article is an open access article distributed under the terms and conditions of the Creative Commons Attribution (CC BY) license (https:// creativecommons.org/licenses/by/ $4.0 /)$.

\begin{abstract}
Transient receptor potential melastatin 4 is a unique member of the TRPM protein family and, similarly to TRPM5, is $\mathrm{Ca}^{2+}$-sensitive and permeable to monovalent but not divalent cations. It is widely expressed in many organs and is involved in several functions by regulating the membrane potential and $\mathrm{Ca}^{2+}$ homeostasis in both excitable and non-excitable cells. This part of the review discusses the pharmacological modulation of TRPM4 by listing, comparing, and describing both endogenous and exogenous activators and inhibitors of the ion channel. Moreover, other strategies used to study TRPM4 functions are listed and described. These strategies include siRNA-mediated silencing of TRPM4, dominant-negative TRPM4 variants, and anti-TRPM4 antibodies. TRPM4 is receiving more and more attention and is likely to be the topic of research in the future.
\end{abstract}

Keywords: TRPM4; SUR1; CBA; flufenamic acid; 9-phenanthrol; siRNA; antibody; TRPM4 activator; TRPM4 inhibitor

\section{Introduction}

Transient receptor potential (TRP) channels were discovered in Drosophila when the structure of a protein fulfilling a role in phototransduction was described in 1989 [1]. The 28 members of the TRP family are divided into six subfamilies based on the sequence homology among the members. These include TRP canonical (TRPC1-7), TRP vanilloid (TRPV1-6), TRP melastatin (TRPM1-8), TRP ankyrin 1 (TRPA1), TRP mucolipin (TRPML13), and TRP polycystin (TRPP2, TRPP3, and TRPP5) [2]. The subfamily of transient receptor potential melastatin (TRPM) consists of eight members (TRPM1-8), forming four pairs based on the similarity in their sequence [3]. A pair is made of TRPM4 and TRPM5, which are unique, as they are only permeable to monovalent but not divalent cations [4,5]. Ion substitution experiments revealed a selectivity sequence of $\mathrm{Na}^{+}>\mathrm{K}^{+}>\mathrm{Cs}^{+}>\mathrm{Li}^{+}$for TRPM4 [6,7]. TRPM4 is activated by intracellular $\mathrm{Ca}^{2+}[8,9]$.

The role of a protein can be examined both in vitro and in vivo. Among these, one must mention the pharmacological intervention of the given protein using compounds modifying its function [4] as well as genetic approaches such as knock-down (KD) or knock-out (KO) [10] and overexpression of the protein [11]. Studying the function in vivo is definitely more complicated, as whole animal models need to be used. These models 
complicate both the pharmacological and genetic approaches, as the compound must be added in a way that provides an effective concentration [12]. Furthermore, KD and/or overexpression might need to be performed in an organ-/tissue-specific manner $[13,14]$. The in vivo approach, however, can be translated to humans more easily than in vitro methods. Evaluating the function of a protein in vitro is a good starting point to understand its function on the level of the whole organism. When modulating (either activating or inhibiting) the channel activity, the selectivity of the applied compound is very important to avoid misinterpreting the results.

This part of the review summarizes the current state of knowledge on the modulation of TRPM4 by endogenous compounds, drugs, and other approaches. Part 2 of the review describes the physiological and pathophysiological roles of TRPM4 in various tissues.

\section{Activation of TRPM4}

Both endogenous and exogenous compounds can increase the TRPM4 current. Some compounds act directly on the channel protein (Figure 1); others have other targets and indirectly increase the TRPM4 current (Figure 2). The first one to mention is intracellular $\mathrm{Ca}^{2+}$ itself [7]. In addition, phosphatidylinositol 4,5-bisphosphate (PIP2) (and its related compounds) $[9,15,16]$ and calmodulin $[11,17]$ must be mentioned as important endogenous compounds activating TRPM4 from the intracellular space. Other compounds, such as decavanadate [18], 3,5-bis(trifluoromethyl)pyrazole derivative (BTP2) (also known as YM58483) [19], $\mathrm{H}_{2} \mathrm{O}_{2}$ [20], tissue plasminogen activator (tPA) [21], U73122 (an inhibitor of phospholipase C) [22], and the adenosine triphosphate-dependent $\mathrm{K}^{+}\left(\mathrm{K}_{\mathrm{ATP}}\right)$ channel activator diazoxide [17], need to be mentioned. Last but not least, phosphorylation induced by protein kinase C (PKC) also increases the TRPM4 current [11].

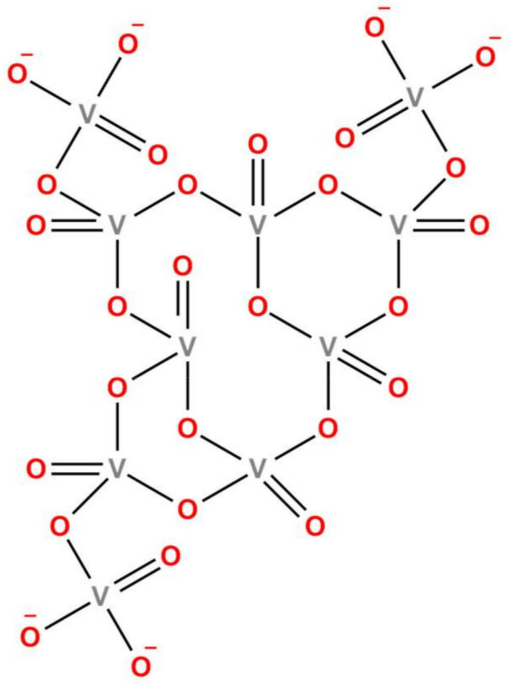

Decavanadate

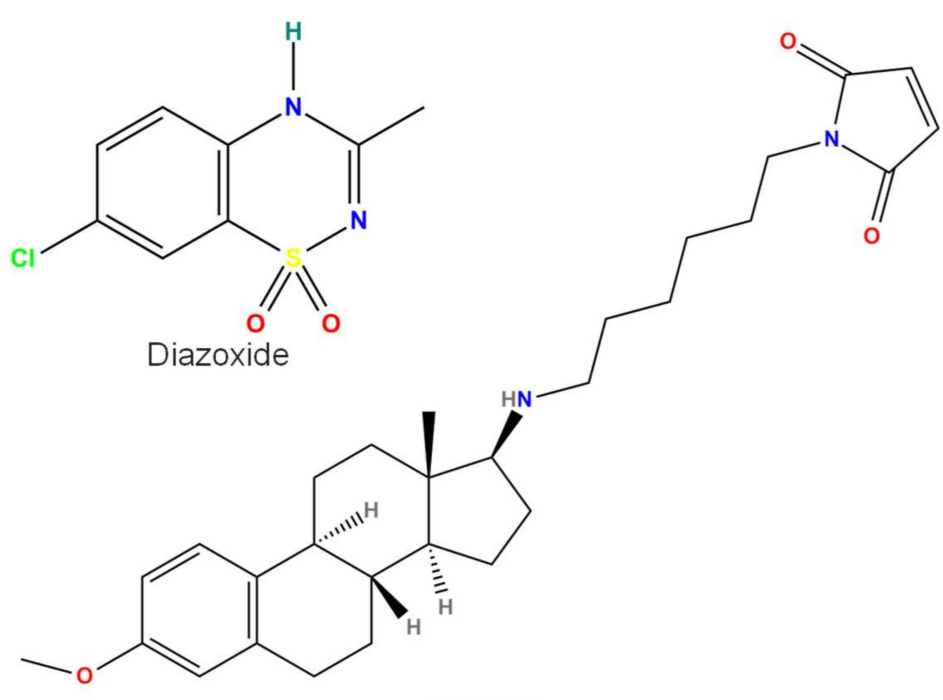

U73122

Figure 1. Chemical structure of compounds directly activating TRPM4 or the sulfonylurea receptor 1 (SUR1)-TRPM4 co-assembled channel (diazoxide). U73122 can also activate TRPM4 in an indirect manner. All structures were created by ChemDrawPro 12.0 software. 
<smiles>Cc1ccc(N(c2ccc(C)cc2)c2c3ccccc3c(N(c3ccc(C)cc3)c3ccc(C)cc3)c3ccccc23)cc1</smiles>

tPA<smiles>CCN[C@H]1CC[C@@H]2[C@]1(C)CC[C@@]1(C)c3ccc(OC)cc3CC[C@]21C</smiles>

U73122

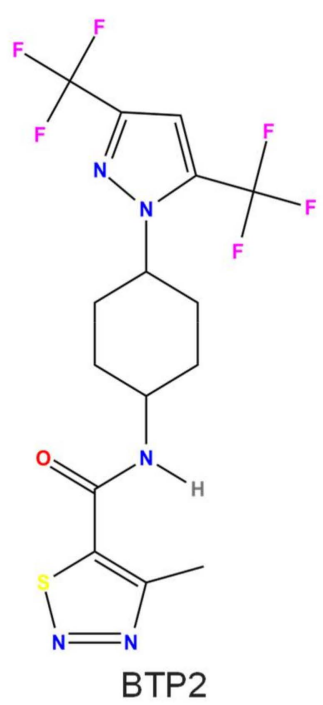

PMA

Figure 2. Chemical structure of compounds activating TRPM4 indirectly. U73122 also activates TRPM4 directly. All structures were created by ChemDrawPro 12.0 software.

\section{1. $\mathrm{Ca}^{2+}$}

As TRPM4 is an ion channel activated by both voltage and $\mathrm{Ca}^{2+}$, a certain minimum concentration of intracellular $\mathrm{Ca}^{2+}$ must be present for its activation. Both the minimum concentration and the value of the half effective activator concentration $\left(\mathrm{EC}_{50}\right)$ depend on several factors, most of which are related to experimental conditions. These include the mode of recording (cell-attached patch, perforated or whole-cell configuration, inside-out patch)—most likely due to the presence or loss of intracellular regulatory compounds-the value of the membrane potential, and the studied preparation (overexpressed or native channels). In addition, it has been well established that even with a given stable free $\mathrm{Ca}^{2+}$ concentration applied to the intracellular side, the TRPM4 current is subjected to rapid desensitization in the range of 1-2 min after the establishment of the recording configuration [16,18]. On the contrary, the TRPM4 current of rat dental follicle stem cells, the HCT116 colorectal cancer cell line, and TRPM4-expressing human embryonic kidney (HEK) cells showed no desensitization despite the tight-seal whole-cell recording condition [23-25]. The reason for this discrepancy is not clear. Gonzales et al. suggested that the proper amount and type of intracellular $\mathrm{Ca}^{2+}$ buffering are required to avoid TRPM4 current desensitization, at least in smooth muscle cells [26]. Interestingly, based on the study of Gonzales et al., desensitization could be avoided only in the HCT116 colorectal cancer cell line recording when 10 mM EDTA (a slower $\mathrm{Ca}^{2+}$ buffer than EGTA) was applied. The other two studies used $10 \mathrm{mM}$ BAPTA as a $\mathrm{Ca}^{2+}$ buffer, so it is not clear why desensitization was not detected. Nevertheless, due to the abovementioned rapid desensitization, the determination of $\mathrm{EC}_{50}$ also depends on the time of determination. Indeed, the $\mathrm{EC}_{50}$ values during the steady state reached after current desensitization were 5 times higher (110 vs. $524 \mu \mathrm{M})$ in excised patches of Chinese hamster ovary (CHO) [16] and 30 times higher (4.4 vs. $140 \mu \mathrm{M})$ in HEK cells [18], both overexpressing human TRPM4. As a result of all the abovementioned factors, the $\mathrm{Ca}^{2+}$ concentration required for TRPM4 activation is reported in a broad range. For instance, the minimum $\mathrm{Ca}^{2+}$ concentration for channel activation detected in the inside-out configuration in native sinoatrial and 
ventricular cardiomyocytes or native $\mathrm{CHO}$ cells was between 0.1 and $1 \mu \mathrm{M}[9,27,28]$. $\mathrm{EC}_{50}$ values of free intracellular $\mathrm{Ca}^{2+}$ were reported in the range of $0.4-80$ and $10-1000 \mu \mathrm{M}$ in the case of whole-cell configuration and inside-out configuration, respectively. The values of the Hill coefficient, if determined, also varied in a broad range from 0.6 to 3.7 in the case of inside-out recordings and even slightly higher (5-6) in whole-cell measurements [7]. The reason for the broad range for values of both the $\mathrm{EC}_{50}$ and Hill coefficients might be due to the different experimental conditions (cell type used, different solutions, and voltage).

$\mathrm{EC}_{50}$ values were also drastically dependent on the presence of PIP2. Application of $10 \mu \mathrm{M}$ diC8-PIP2 (the water-soluble and nonmetabolizable form of PIP2) in a pipette increased $\mathrm{Ca}^{2+}$ sensitivity by 100 times (from 134 to $1.3 \mu \mathrm{M}$ ) [15] in HEK cells and 5 times (from 524 to $123 \mu \mathrm{M}$ ) in $\mathrm{CHO}$ cells [16]. Surprisingly, the Hill coefficient did not change after the application of PIP2 in HEK cells ( 0.9 and 1.0) but doubled in CHO cells (1.5 vs. 2.9). The effect of PIP2 is also discussed in detail later.

The binding site for $\mathrm{Ca}^{2+}$ was also described in detail recently. Four amino acids (Glu828, Gln831, Asn865, and Asp868) located close to the S3 transmembrane helix in hsTRPM4 coordinate a $\mathrm{Ca}^{2+}$ ion [29-31]. As TRPM4 functions as a homo- or heterotetramer [32], the abovementioned Hill coefficients exceeding a value of 1 might be due to the binding of one $\mathrm{Ca}^{2+}$ ion to each unit of the tetramer.

Recently, the $\mathrm{K}^{+}$channel tetramerization domain 5 protein was indicated as a novel TRPM4-interacting protein, which enhances the $\mathrm{Ca}^{2+}$ sensitivity of TRPM4 and thereby promotes the cell migration and contractility observed in breast cancer [33]. Similarly, Rho-associated protein kinase also activates TRPM4 by increasing its $\mathrm{Ca}^{2+}$ sensitivity and is involved in the regulation of myogenic tone [34].

\subsection{Phosphatidylinositol 4,5-Bisphosphate (PIP2)}

TRPM4 activation is very effectively facilitated by the presence of intracellular PIP2 (IUPAC name: [(1R,2S,3R,4R,5S,6R)-2,3,5-trihydroxy-4-[[2-[(5Z,8Z,11Z,14Z)-icosa-5,8,11,14tetraenoyl]oxy-3-octadecanoyloxypropoxy]-oxidophosphoryl]oxy-6-phosphonatooxycyclo hexyl] phosphate) [16]. The molecule activates the channels by increasing their sensitivity to $\mathrm{Ca}^{2+}$ and shifting their activating voltage to more negative potentials [15]. PIP2 had an $\mathrm{EC}_{50}$ of 5.1-5.8 $\mu \mathrm{M}$ and a Hill coefficient of 2.1-2.6 to activate TRPM4 (i.e., recover the channel from desensitization), but other related compounds can also modulate TRPM4 [15,16]. The number of phosphate groups in the molecule is important, as doubly phosphorylated PIs such as PI $(3,4) \mathrm{P} 2$ and $\mathrm{PI}(3,5) \mathrm{P} 2$ were equally effective, and the monophosphorylated form PI(4)P had no effect, while the triple-phosphorylated PI(3,4,5)P3 was more effective than PIP2 itself [16]. On the contrary, the triple-phosphorylated PI(3,4,5)P3 was less effective than PIP2 itself, and the double-phosphorylated forms showed similar activity to PI $(3,4,5) \mathrm{P} 3$ [15]. In addition, among the monophosphorylated forms, PI(5)P had similar effectivity to the triple-phosphorylated PI(3,4,5)P3, but PI(3)P and PI(4)P were ineffective [15]. This suggests that phosphorylation on position 5 makes the molecule more effective in inducing recovery from the desensitization of TRPM4. The two previously mentioned studies were conducted on expressed TRPM4 channels, but $10 \mu \mathrm{M}$ PIP2 tripled the open probability of native TRPM4 channels of freshly isolated murine sinoatrial node cells, even with $1 \mu \mathrm{M}$ free intracellular $\mathrm{Ca}^{2+}$ concentration [9]. Another approach for the evaluation of the role of PIP2 is to stimulate a phospholipase C (PLC)-coupled signaling pathway or to apply a PLC inhibitor (5 $\mu \mathrm{M}$ U73122) to prevent the degradation of PIP2. This latter approach greatly enhanced $\mathrm{Ca}^{2+}$ sensitivity in the case of TRPM4 channels on murine renal primary cilia [35]. Another strategy to prove the importance of PIP2 for TRPM4 is to reduce the PIP2 concentration by either applying the PIP2 scavenger poly-L-lysine [16], delaying the regeneration of PIP2 by applying wortmannin, the inhibitor of PI-4-kinase, or using inositol polyphosphate 5-phosphatases [15]. Cai et al. showed that cholesterol activates TRPM4 via a PIP2-dependent mechanism in murine cortical collecting duct cells by increasing its $\mathrm{Ca}^{2+}$ sensitivity [36]. 
The binding site for PIP2 was suggested to be located on the first putative pleckstrin homology domain located on the C-terminus of the protein [15]. Alternatively, the pre-S1 region of the N-terminus was proposed to host the PIP2 binding site [37]. Arg755 and Arg767 of hTRPM4 were shown to be crucial in the interaction with PIP2 [31]. Recently, another site located on the C-terminus was indicated for PIP2 binding [38].

PIP2 was shown to interfere with other ion channels of the TRP family, including the tonic inhibition of TRPV1 [39]. Other TRP channels such as TRPM5 [40], TRPM7 [41], TRPM8 [42], and TRPV5 [43,44] are activated by PIP2. Other non-TRP ion channels are also activated by PIP2. TREK1 and KCNQ1 are activated by PIP2 by shifting their activation curves to more negative potentials [45]. P/Q-type $\mathrm{Ca}^{2+}$ channels are influenced by $20 \mu \mathrm{M}$ PIP2 in two opposing ways: stabilization of channel activity and voltage-dependent inhibition [46]. Cloned and native $\mathrm{N}$-type $\mathrm{Ca}^{2+}$ channels are also modulated by PIP2, as $10 \mu \mathrm{M}$ reversed the rundown of their current [47]. Furthermore, PIP2 influences other ion channels, such as voltage-gated, inwardly rectifying, and $\mathrm{Ca}^{2+}$-activated potassium channels [48]. In addition, voltage-gated $\mathrm{Ca}^{+}$channels, TRP channels, epithelial $\mathrm{Na}^{+}$channels, P2X receptors, TMEM16A channels, and cyclic nucleotide-gated channels are on the long list of ion channels affected by PIP2 [48]. As the concentration of PIP2 required to stimulate TRPM4 is in a similar range to that which affects other ion channels, it seems that PIP2 application in a native cell is not selective enough to study the function of TRPM4.

\subsection{Calmodulin}

TRPM4 is also modulated by the presence of calmodulin [11,17]. In HEK cells transiently expressing human TRPM4, the effect of calmodulin was studied by either adding calmodulin to the intracellular side of the channels, which doubled the open probability, or by using dominant-negative calmodulin mutants. The mutation or deletion of the three calmodulin binding sites located in a short range of the C-terminus enhanced TRPM4 activation by $\mathrm{Ca}^{2+}$ and delayed its desensitization. In contrast, mutation or deletion of the two calmodulin binding sites at the N-terminus did not affect TRPM4 function [11]. Woo et al. reported doubled calmodulin binding affinity upon coexpression of sulfonylurea receptor 1 (SUR1) with TRPM4 channels compared with that of TRPM4 alone [17]. Two additional binding sites located at the $\mathrm{N}$ - and C-termini were identified as capable of binding calmodulin, S100A1, and PIP2 [38].

\subsection{Decavanadate}

TRPM4 activity is enhanced by the intracellular application of the six negative charges contained within decavanadate (DV, IUPAC name: [5,13-bis[(dioxido(oxo)vanadio)oxy] -1,3,5,7,9,11,13-heptaoxo-2,4,6,8,10,12,14,15,16-nonaoxa-1lambda5,3lambda5,5lambda5, 71 ambda5,9lambda5,11lambda5,13lambda5-heptavanadatricyclo[9.3.1.13,7]hexadecan-9-yl] oxy-dioxido-oxovanadium, Figure 1), the decamer form of vanadate [18]. When applied to the intracellular side of a patch made from HEK cells containing transiently expressed human TRPM4 channels, $10 \mu \mathrm{M}$ DV induced a fast and fully reversible increase in the inward current but hardly changed outward currents, indicating a strong effect on the voltage-dependent gating of TRPM4. The DV-induced increase in inward currents was concentration-dependent, having an $\mathrm{EC}_{50}$ of $1.9 \mu \mathrm{M}$ and a Hill coefficient of 1.8 [18]. The maximum current increase was 2.5 times compared with that in the absence of DV. In addition, adenosine triphosphate (ATP)-induced TRPM4 inhibition was increased in the presence of $5 \mu \mathrm{M}$ DV by 10 times, but its voltage dependence was unaltered. This makes the competitive binding of ATP and DV unlikely. Deletion of the highly positively charged 1136RARDKR sequence from the C-terminus but not the 332RDRIRR sequence from the $\mathrm{N}$ terminus resulted in the loss of the DV effect, suggesting the importance of the C-terminal site in mediating DV action [18]. The abovementioned Hill coefficient value (nearly 2) suggests two binding sites with positive cooperativity. Although the N-terminal site was not suggested to be important to DV action, Winkler et al. reported two functional DV binding sites [49]. One of these was the previously mentioned site on the C-terminus containing six 
positively charged amino acids, and another one is located in the interface between TRPM homology regions $1 / 2$ and 3 from the adjacent subunit of the TRPM4 tetramer, where three positively charged arginine residues are found [49].

In addition to TRPM4, DV acts on P2X-type purinergic receptors [50]. P2X7 receptors expressed in HEK cells were the most sensitive, but decavanadate also blocked P2X2 and P2X4 receptors. DV at a concentration of $10 \mu \mathrm{M}$ induced an almost complete blockade of inward currents of P2X7 receptors in a rapid and reversible manner [50]. In permeabilized rat pancreatic acinar cells, DV antagonizes the binding of inositol 1,4,5-trisphosphate (IP3) to its receptors, with an $\mathrm{EC}_{50}$ of $5 \mu \mathrm{M}$, and $20 \mu \mathrm{M}$ DV was required for complete inhibition [51]. Inhibition of $\mathrm{Ca}^{2+}$-ATPase of the sarcoplasmic reticulum required at least $40 \mu \mathrm{M}$ DV [52]. These data indicate that the application of DV in cellular preparations is not suitable for studying TRPM4.

\subsection{BTP2 or $Y M-58483$}

TRPM4 activity was increased by the compound called 3,5-bis(trifluoromethyl)pyrazole derivative (BTP2), also known as YM-58483 (IUPAC name: N-[4-3,5-bis (trifluromethyl)pyrazol-1-yl]-4-methyl-1,2,3-thiadiazole-5-carboxamide, Figure 2) [19]. It must be noted that BTP2 is often used as an inhibitor of the mainly ORAI channel-mediated $\mathrm{Ca}^{2+}$-release-activated current [53]. In HEK cells overexpressing TRPM4, BTP2 was only effective in the presence of some $\mathrm{Ca}^{2+}$, and preincubation with $10 \mu \mathrm{M}$ BTP2 resulted in much higher TRPM4 currents. BTP2 increased the native TRPM4 current of Jurkat cells in a concentration-dependent manner with an $\mathrm{EC}_{50}$ of $8 \mathrm{nM}$ [19]. Regarding the specificity of BTP2, it must be noted that in Jurkat cells, the $\mathrm{Ca}^{2+}$-release-activated current is inhibited in a range from 0.5 to $4 \mu \mathrm{M}$, and a similar concentration was needed to inhibit TRPC3 and TRPC5 channels [54], so BTP2, if applied at low enough concentrations, can be a useful tool to investigate TRPM4 in native cells too.

\section{6. $\mathrm{H}_{2} \mathrm{O}_{2}$}

The desensitization of TRPM4 channels overexpressed in HEK cells can be eliminated in a dose-dependent manner by $\mathrm{H}_{2} \mathrm{O}_{2}$ [20]. This effect was observed both in whole-cell and inside-out recording configurations and can be detected starting from $50 \mu \mathrm{M}$. HeLa cells were less sensitive to $\mathrm{H}_{2} \mathrm{O}_{2}$-induced cell death. The TRPM4 mutation of Cys1093Ala reduced the sensitivity to $\mathrm{H}_{2} \mathrm{O}_{2}$ but not to PIP2. Therefore, Simon et al. suggested that redox modifications of the Cys1093 residue could increase calmodulin binding, leading to reduced desensitization of TRPM4 [20]. Pretreatment of the cardiomyocyte cell line $\mathrm{H} 9 \mathrm{c} 2$ with $200 \mu \mathrm{M} \mathrm{H}_{2} \mathrm{O}_{2}$ induced cell death. Silencing of TRPM4 and pretreatment with 9-phenanthrol, a TRPM4 inhibitor, prevented $\mathrm{H}_{2} \mathrm{O}_{2}$-induced cell death [55]. $\mathrm{H}_{2} \mathrm{O}_{2}$-induced TRPM4 stimulation was described in human umbilical vein endothelial cells [56]. In addition, the expression of TRPM4 was increased by $200 \mu \mathrm{M} \mathrm{H}_{2} \mathrm{O}_{2}$ in those cells [57]. Importantly, in mpkCCDc14 cells, TRPM4 activity in a mouse cortical collecting duct principal cell line was not influenced by even $500 \mu \mathrm{M} \mathrm{H}_{2} \mathrm{O}_{2}$, but $100 \mu \mathrm{M} \mathrm{H}_{2} \mathrm{O}_{2}$ pretreatment for $24 \mathrm{~h}$ significantly reduced TRPM4 expression on the apical membrane, suggesting that $\mathrm{H}_{2} \mathrm{O}_{2}$ inhibits its trafficking [58]. At a higher concentration (10 mM), $\mathrm{H}_{2} \mathrm{O}_{2}$ activated TRPM2 channels of both primary lens epithelial cells and the cell line HLE-B3 [59]. Other TRP channels are also sensitive to redox changes: $\mathrm{H}_{2} \mathrm{O}_{2}$ activated TRPM2, TRPC5, TRPV1, and TRPA1 too [60].

\subsection{Tissue Plasminogen Activator (tPA)}

In murine brain endothelial cells, tPA (Figure 2) opened SUR1-TRPM4 channels in a plasmin-, PAR1-, TRPC3-, and $\mathrm{Ca}^{2+}$-dependent manner [21]. Recombinant tPA (20 $\left.\mu \mathrm{g} / \mathrm{mL}\right)$ induced both macroscopic and single-channel SUR1-TRPM4 currents. De novo expression of SUR1-TRPM4 channels in response to NF- $k B$ activation was also observed [21]. Other targets of tPA include toll-like receptors in CSF-1 macrophages, which are selectively inhibited by $12 \mathrm{nM}$ tPA [61], and $N$-methyl-D-aspartic acid (NMDA) receptors purified 
from the cerebral cortex of C57BL/6mice, which mediate the effect of 12-100 nM tPA [62]. Calculating the tPA concentration used by Gerzanich et al. yields approximately $286 \mathrm{nM}$, which is at least 3 times higher than that in the other two previously mentioned studies. Thus, tPA is definitely not a good choice to study TRPM4 function in cellular preparations.

\subsection{U73122}

U73122 (IUPAC name: 1-[6-[[(8R,9S,13S,14S,17S)-3-methoxy-13-methyl-6,7,8,9,11, 12,14,15,16,17-decahydrocyclopenta[a]phenanthren-17-yl]amino]hexyl]pyrrole-2,5-dione, Figures 1 and 2) is an inhibitor of phospholipase C, and therefore, it is often used to study the effect of PIP2 on the activity of various ion channels, including TRPM4 (see above). U73122 influenced TRPM4 via direct interaction: activation of TRPM4 by $5 \mu$ M U73122 was independent of PIP2 and $\mathrm{Ca}^{2+}$ [22]. Interestingly, TRPM5 channels were not influenced, but TRPM3 channels were blocked by $5 \mu \mathrm{M}$ U73122, indicating the high specificity of U73122 within the TRPM channel family [22]. U73343, a compound used as a negative control (not inhibiting phospholipase C), induced almost the same effect as U73122 on $\mathrm{I}_{\mathrm{KAch}}$ of mouse atrial myocytes: full inhibition by $10 \mu \mathrm{M}$ and a half inhibitory concentration $\left(\mathrm{IC}_{50}\right)$ value of $160 \mathrm{nM}$, slightly higher than that of U73122 (120 nM) [63]. Similarly, in HEK cells, both U73122 and U73343 potently blocked expressed BK and Kir3 channels, most likely by acting on their homologous domain within long C-terminal ends [64]. G-protein-coupled inward rectifier $\mathrm{K}^{+}$channels are also significantly blocked by $1 \mu \mathrm{M}$ U73122 and even more potently blocked by $1 \mu \mathrm{M}$ U73343 [65]. In addition, $10 \mu \mathrm{M}$ U73122 activated $\mathrm{Ca}^{2+}$ release from intracellular stores of mouse pancreatic acinar cells in a phospholipase $C$-independent manner [66]. Studies that use the compound as a PLC inhibitor usually apply 5-10 $\mu \mathrm{M}$ U73122 [15,35]. It seems that U73122 is not selective enough and, therefore, at least in native cells, definitely cannot be used as a TRPM4 activator.

\subsection{Diazoxide}

The most well-known action of diazoxide (IUPAC name: 7-chloro-3-methyl-4H1lambda6,2,4-benzothiadiazine1,1-dioxide, Figure 1) is the activation of $\mathrm{K}_{\text {ATP }}$ channels, enabling its use in the treatment of hypoglycemia [67]. As mentioned earlier, TRPM4 can form heteromer channels with SUR1, a subunit of $\mathrm{K}_{\text {ATP }}$ channels [68]. Therefore, it is not surprising that diazoxide influences TRPM4-SUR1 coexpressed channels in COS-7 cells [17]. In these coexpressed channels, $100 \mu \mathrm{M}$ diazoxide greatly increased the current (approximately by 15 times) but had no effect in cells expressing either TRPM4 or SUR1 alone. Diazoxide at a concentration of $100 \mu \mathrm{M}$ also strongly activated native TRPM4-SUR1 channels in human brain endothelial cells [21]. As diazoxide non-selectively activates $\mathrm{K}_{\text {ATP }}$ channels, it stimulates Kir6.2/SUR1 channels in $\beta$-cells, Kir6.2/SUR2B and Kir6.1/SUR2B channels of smooth muscle, and, to a small extent, also cardiac Kir6.2/SUR2A channels [69]. As TRPM4 can function without SUR1 and $\mathrm{K}_{\text {ATP }}$ channels potentially exist in native cells, it is unlikely that diazoxide can be used as an activator of TRPM4 currents, or at least caution must be applied.

\subsection{PKC-Mediated Phosphorylation}

TRPM4 currents are increased by the phosphorylation of TRPM4 channels by PKC. The PKC activator phorbol 12-myristate 13-acetate (PMA, IUPAC name: [(1S,2S,6R,10S,11R,13S, 14R,15R)-13-acetyloxy-1,6-dihydroxy-8-(hydroxymethyl)-4,12,12,15-tetramethyl-5-oxo-14tetracyclo[8.5.0.02,6.011,13]pentadeca-3,8-dienyl] tetradecanoate, Figure 2), applied in a $1 \mathrm{~h}$ preincubation at $1 \mu \mathrm{M}$ in HEK cells transiently expressing human TPRM4, reduced the EC $\mathrm{E}_{50}$ value for $\mathrm{Ca}^{2+}$ from 15 to $4 \mu \mathrm{M}$ [11]. Moreover, the chance for TRPM4 activation by $1 \mu \mathrm{M}$ $\mathrm{Ca}^{2+}$ greatly increased in the case of PMA pretreatment from 3 of 12 cells to 7 of 10 cells. A similar effect was observed with 10 min pretreatment with $0.5 \mu \mathrm{M}$ PMA in inside-out TRPM4 current detection (probably by increasing $\mathrm{Ca}^{2+}$ sensitivity) in various native cell types, including dedifferentiated ventricular cardiomyocytes [70], freshly dissociated human right atrial cells [4], and ventricular cells isolated from spontaneously hypertensive 
rats [27]. The sites responsible for the action include the serine amino acids at positions 1145 and 1152, as their mutation to alanine led to the loss of effectivity of PMA [11].

\section{Inhibition of TRPM4}

Several compounds block TRPM4 current (Figures 3-6). Some of these are endogenous molecules, such as adenosine triphosphate (ATP) (and other related molecules) [71], nitric oxide (NO) [72], and spermine [71]. Others are exogenous compounds, including quinine [73], MPB-104 [74], the nonsteroid anti-inflammatory compound flufenamic acid (FFA) [75], the antidiabetic drug glibenclamide [4], the antimycotic drug clotrimazole [76], chloride channel blockers (such as diphenylamine-2-carboxylic acid (DPC), 3' ,5dichlorodiphenylamine-2-carboxylic acid (DCDPC), and 5-nitro-2-(3-phenylpropylamino) benzoic acid (NPPB)) [77], and 9-phenanthrol [77]. The selectivity of these compounds is, in many cases, rather weak, necessitating the search for and testing of newer and newer compounds. Such recently developed drugs are 4-chloro-2-[[2-(2-chlorophenoxy)acetyl]amino] benzoic acid (CBA), 4-chloro-2-(1-naphthyloxyacetamido)benzoic acid (NBA), and 4-chloro2-(2-(4-chloro-2-methylphenoxy)propanamido) benzoic acid (LBA) [78,79]. Moreover, especially in in vivo studies, either specific antibodies M4P, M4M, and M4M1 were used to block TRPM4 [80,81], or small-interfering RNAs (siRNA) were applied to silence TRPM4 [82]. This latter approach was used in vitro as well [35].<smiles>[2H]Oc1c(CCCC)c2cccc[n+]2c2cccc(Cl)c12</smiles>

MPB-104<smiles>NCCCNCCCCNCCCN</smiles>

Spermine

Figure 3. Chemical structure of compounds causing TRPM4 inhibition via a putative binding site. All structures were created by ChemDrawPro 12.0 software. 
<smiles>O=C(O)c1ccccc1Nc1ccccc1</smiles>

DPC<smiles>O=C(OI)c1ccc(Cl)cc1Nc1cccc(Cl)c1</smiles>

DCDPC<smiles>[2H]OC(=O)c1cc([N+](=O)[O-])ccc1NCCCc1ccccc1</smiles>

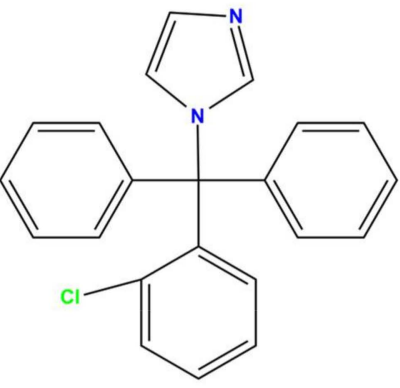

Clotrimazole

Figure 4. Chemical structure of compounds causing TRPM4 inhibition in a nonspecific manner. All structures were created by ChemDrawPro 12.0 software.
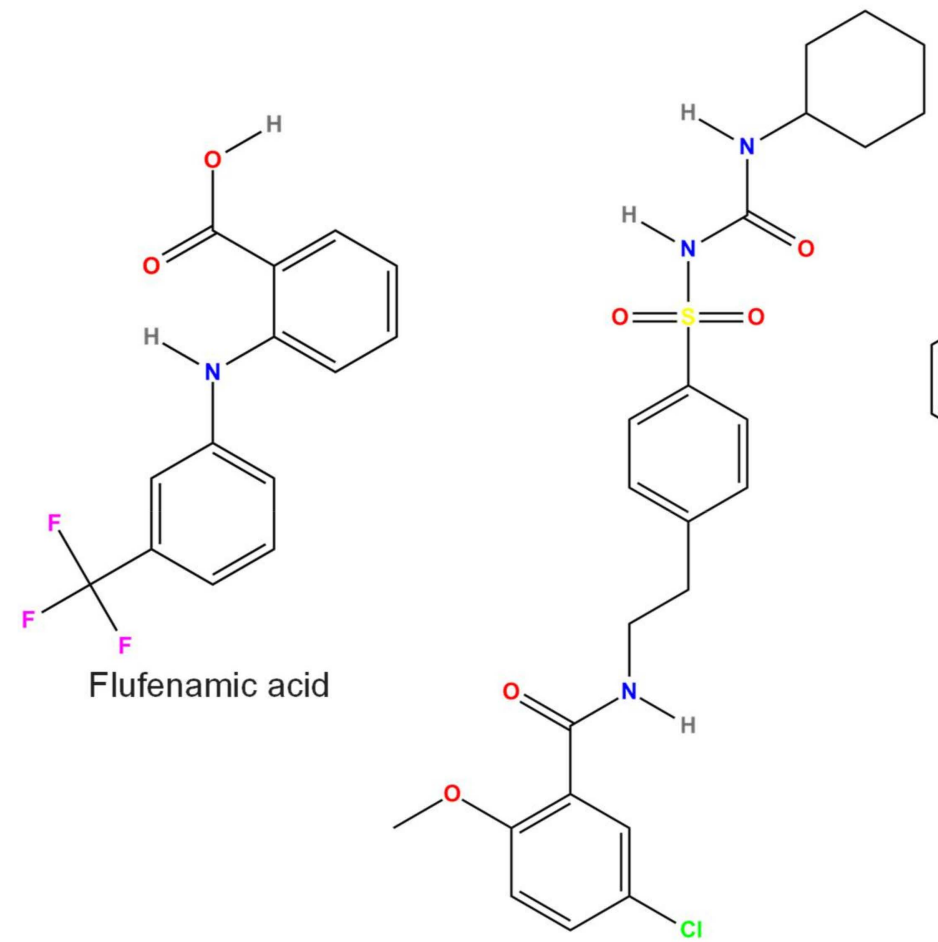<smiles>Oc1cc2ccccc2c2ccccc12</smiles>

9-phenanthrol

Flufenamic acid

\section{Glibenclamide}

Figure 5. Chemical structure of compounds widely used for TRPM4 inhibition. All structures were created by ChemDrawPro 12.0 software. 


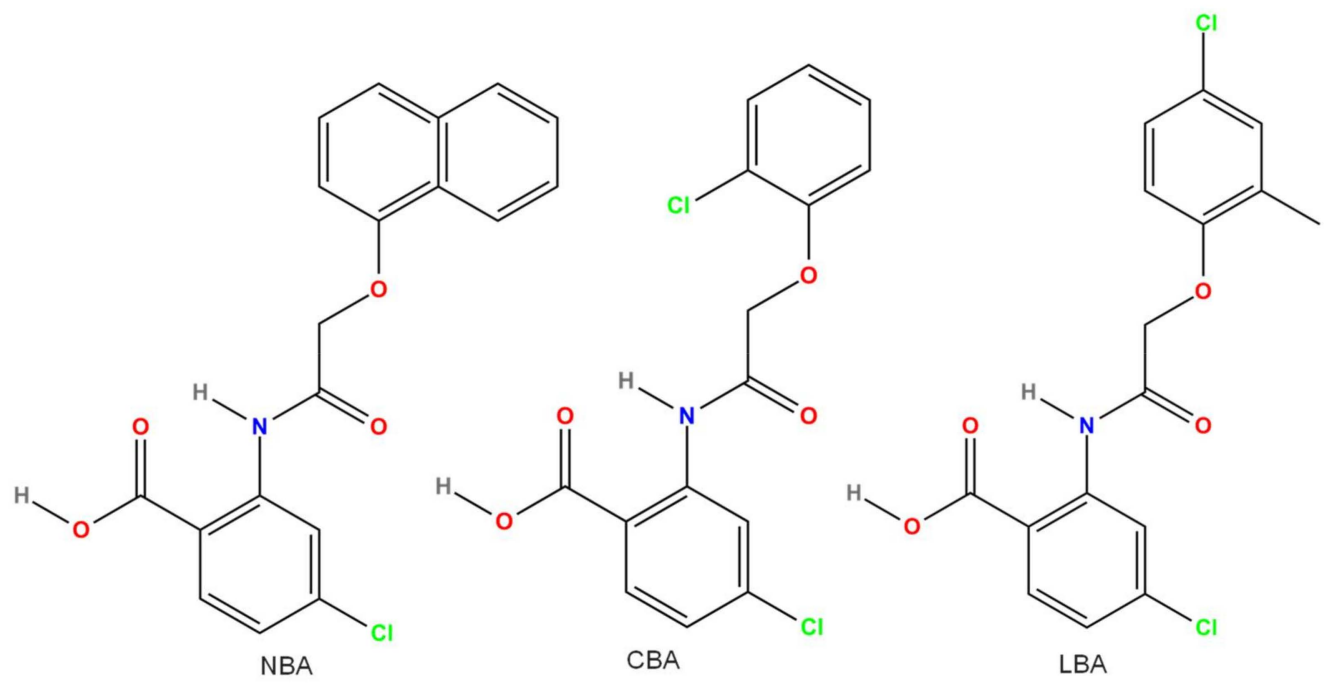

Figure 6. Chemical structure of the newest TRPM4 inhibitors. All structures were created by ChemDrawPro 12.0 software.

Lastly, some studies have used the approach of using dominant-negative TRPM4 splice variants to study the contribution of the channel to physiological processes.

\subsection{Adenosine Triphosphate (ATP)}

As TRPM4 can form heteromer channels with SUR1, a subunit of $\mathrm{K}_{\mathrm{ATP}}$ channels, it is not surprising that ATP (IUPAC name: [[(2R,3S,4R,5R)-5-(6-aminopurin-9-yl)-3,4dihydroxyoxolan-2-yl]methoxy-hydroxyphosphoryl] phosphono hydrogen phosphate) and other related compounds can inhibit TRPM4 [71]. There is, however, a discrepancy between the action of ATP and that of diazoxide (see above), despite the fact that both of these compounds act on $\mathrm{K}_{\mathrm{ATP}}$ channels. It is not the direction of action (ATP blocks and diazoxide stimulates) but rather the abundance of data reporting ATP-induced TRPM4 inhibition in both the presence and absence of SUR1 in the channel. On the contrary, diazoxide-mediated activation of TRPM4 was only observed when SUR1 was also expressed with TRPM4 (see above).

Another intriguing fact is that MgATP increased TRPM4 currents (or, to be precise, reversed the desensitization of the current), which was not detected with ATP alone [11] or with Na2ATP, MgADP, and MgGTP [16]. These observations make it unlikely that $\mathrm{Mg}^{2+}$ itself plays a role, and the most accepted explanation for the MgATP-induced recovery of TRPM4 currents is the ability of MgATP to activate phosphatidylinositol 4-kinase. This kinase is able to regenerate PIP2 [83], the compound that was mentioned above to stimulate TRPM4. It is noteworthy that $2 \mathrm{mM} \mathrm{MgATP}$ reversibly inhibited $87 \%$ of the total $\mathrm{Ca}^{2+}$-activated current in murine renal primary cilia [35], but the authors concluded that it is likely due to the direct inhibition of ATP and the very low level of PIP2 and/or phosphatidylinositol 4-kinase. Another explanation for the increase in TRPM4 currents by MgATP may be the presence of SUR1, as it is proposed to be facilitated by MgATP [84].

As mentioned before, not only ATP itself but also related compounds such as ADP, AMP, and AMP-PNP reduced the TRPM4 current expressed in HEK cells [71]. These compounds induced inhibition with $\mathrm{IC}_{50}$ values of $1.7 \mu \mathrm{M}$ (free ATP), $2.2 \mu \mathrm{M}$ (ADP), and $19 \mu \mathrm{M}$ (AMP and AMP-PNP); in addition, adenosine itself blocked TRPM4 too, with a much higher $\mathrm{IC}_{50}$ value $(630 \mu \mathrm{M})$. On the contrary, GTP, UTP, and CTP at concentrations up to $1 \mathrm{mM}$ did not inhibit the current [71]. Sensitivity to ATP was observed not only for the TRPM4 channels expressed in HEK cells but also for TRPM4 channels endogenously present in $\mathrm{CHO}$ cells, which were effectively blocked by $100 \mu \mathrm{M}$ ATP, ADP, and AMP (reduction in the open probability of 90-99\%) [28]. Furthermore, in other cells, including murine sinoatrial node cells [9], vomeronasal sensory neurons [85], dedifferentiated rat 
ventricular cells [70], left ventricular cells of spontaneously hypertensive rats [27], and human right atrial cells [4], ATP reduced the open probability of TRPM4 channels. The binding site of ATP can be at the intersubunit interface between the nucleotide binding domain and ankyrin repeat domain. In more detail, three amino acids-His160, Trp214, and Phe228 - can take part in ATP binding, the first one having particular importance [86]. Surprisingly, ATP inhibited both TRPM4 and SUR1-TRPM4 channels with a similar potency, but ADP and AMP did not block SUR1-TRPM4 channels [87].

ATP is a powerful inhibitor of TRPM4, but because it also blocks $\mathrm{K}_{\mathrm{ATP}}$ channels, it is not used to study the role of TRPM4 channels.

\subsection{Nitric Oxide (NO)}

Nitric oxide inhibited a current possessing similar characteristics to those of TRPM4 in macrovascular endothelial cells, as several NO donor compounds, such as sodium nitroprusside, S-nitroso- $N$-acetylpenicillamine, and 3-morpholinosydnonimine, all reduced the current when applied at 10-30 $\mathrm{MM}$ [72]. The inhibition developed slowly and was voltage-independent. Inhibition of NO breakdown by superoxide dismutase led to current reduction, while nitro-L-arginine (NO synthase inhibitor) potentiated the current [72]. Interestingly, NO reduced TRPM4 channels indirectly via IP3R-associated PKG substratemediated inhibition of IP3R-dependent $\mathrm{Ca}^{2+}$ release in vascular smooth muscle cells [88]. NO (applied as $100 \mu \mathrm{M}$ sodium nitroprusside) blocked the $\mathrm{K}_{\mathrm{ATP}}$ channels of pancreatic $\beta$-cells [89]. These $\mathrm{K}_{\text {ATP }}$ channels were activated by $100 \mu \mathrm{M}$ L-arginine-generated $\mathrm{NO}$ in vascular smooth muscle cells [90]. The $N$-methyl-D-aspartate receptor channel was also influenced by NO via S-nitrosylation [91], and cardiac L-type $\mathrm{Ca}^{2+}$ channels were likely to be blocked by $\mathrm{NO}$ [92]. Large-conductance $\mathrm{Ca}^{2+}$-dependent $\mathrm{K}^{+}$channels and other $\mathrm{K}^{+}$ channels were also activated by $10 \mu \mathrm{M}$ NO in canine colonic smooth muscle cells [93]. As $\mathrm{NO}$ is a short-lived molecule and has several other ion channels among its targets, it is not used as a TRPM4 inhibitor.

\subsection{Spermine}

TRPM4 can be blocked by spermine (IUPAC name: $N, N^{\prime}$-bis(3-aminopropyl)butane1,4-diamine, Figure 3), an endogenous polyamine [94]. In HEK cells expressing the murine TRPM4 or TRPM5 (its closest relative) channels, intracellularly applied spermine induced similar inhibition of both channels ( $\mathrm{IC}_{50}$ values of 35 and $37 \mu \mathrm{M}$, respectively) [8]. Human TRPM4 expressed in HEK cells is also sensitive to spermine $\left(\mathrm{IC}_{50}\right.$ of $\left.61 \mu \mathrm{M}\right)$, and the negatively charged amino acid residues of E981, D982, D984, E988, and E996 were suggested to be responsible for the binding [71]. Spermine at a concentration of $1 \mathrm{mM}$ reduced not only expressed but also endogenous TRPM4 currents by approximately $60 \%$ in $\mathrm{CHO}$ cells [28]. Spermine, similarly to other polyamines, is not specific for TRPM4, as inward rectification of the expressed Kir2.1 channel was increased by $20 \mu \mathrm{M}$ spermine [95]. Among glutamatergic receptors, kainate receptors were potentiated [96], but AMPA receptors were blocked by spermine [97]. At $20 \mu \mathrm{M}$, spermine greatly reduced TRPM7 current as well [98]. Spermine, similarly to NO, modifies the function of many other ion channels besides TRPM4; therefore, it is not used as a TRPM4 inhibitor.

\subsection{Quinine}

Quinine (IUPAC name: (R)-[(2S,4S,5R)-5-ethenyl-1-azabicyclo[2.2.2]octan-2-yl]-(6methoxyquinolin-4-yl)methanol, Figure 4) reversibly blocked human TRPM4 channels overexpressed in HEK cells in a dose- and voltage-dependent manner, with $\mathrm{IC}_{50}$ values of approximately 100-500 $\mu \mathrm{M}$ [73]. TRPM5 was even more sensitive, as the $\mathrm{IC}_{50}$ of quinine was $50 \mu \mathrm{M}$ at $-50 \mathrm{mV}$ vs. $450 \mu \mathrm{M}$ for TRPM4. In addition, TRPM7 and small-conductance $\mathrm{Ca}^{2+}$-activated $\mathrm{K}^{+}$channels (Kca1.1 and Kca3.1) were also inhibited by $30 \mu \mathrm{M}$ quinine [99]. Due to the lack of selectivity, quinine is not suitable for examining the role of TRPM4. 


\subsection{MPB-104}

The cystic fibrosis transmembrane conductance regulator (CFTR) channel activator MPB-104 (IUPAC name: 5-butyl-7-chloro-6-hydroxybenzo[c]quinolizinium chloride, (Figure 3) [100] blocked TRPM4 channels permanently expressed in HEK cells [74]. MPB104 reduced TRPM4 when applied from the intracellular side during inside-out recording without a significant effect on single-channel conductance. The inhibition was rapid, reversible, voltage-independent, and achieved with $\mathrm{IC}_{50}$ values in the range of $10-20 \mu \mathrm{M}$. CFTR-dependent ion efflux was activated by $250 \mu \mathrm{M}$ MPB-104 [74]. The $\mathrm{EC}_{50}$ value of MPB-104 on CFTR activation was approximately $2 \mu \mathrm{M}$, measured as ion flux in CFTR channels expressed in CHO cells [101]. The suggested binding site for MPB-104 is an ABC signature-like motif in both CFTR and TRPM4; however, the fact that the former channel is activated but the latter one is blocked by the compound suggests a different mechanism of action and still needs to be confirmed. Nevertheless, MPB-104, similarly to the previously mentioned inhibitors, has not been applied as a TRPM4 inhibitor.

\subsection{Flufenamic Acid (FFA)}

The nonsteroid anti-inflammatory compound FFA (IUPAC name: 2-[3-(trifluoromethyl) anilino]benzoic acid, Figure 5) was widely used as a promising TRPM4 blocker, especially in the beginning of TRPM4 research. An excellent review summarized the role of FFA in research by describing the effects of FFA on many ion channels and its effects at various levels (starting from molecular and ending at the whole system) [75]. FFA is not selective, as its $\mathrm{IC}_{50}$ for TRPM4 is between 3 and $6 \mu \mathrm{M}[8,27]$, whereas for expressed GABA-induced or voltage-gated chloride currents, it is between 4 and $20 \mu \mathrm{M}[102,103]$. For any other ion channels influenced by FFA, the $\mathrm{EC}_{50}$ (or $\mathrm{IC}_{50}$ ) values are at least $20 \mu \mathrm{M}$ and range as high as $1 \mathrm{mM}$ [75]. These half effective concentrations provide a large enough "therapeutic window" for FFA. As both expressed [20] and native TRPM4 channels [4,104] can be blocked by FFA, it is still used to study the function of TRPM4. This is highlighted by the fact that even after the emergence of 9-phenathrol, a more selective TRPM4 inhibitor, in 2008 (see below), FFA was still used in a few studies [105-107], although in most cases, it was compared with 9-phenathrol.

\subsection{Glibenclamide}

As was mentioned previously, TRPM4 can form heteromer channels with SUR1. Glibenclamide (IUPAC name: 5-chloro- $N$-[2-[4-(cyclohexylcarbamoylsulfamoyl)phenyl] ethyl]-2-methoxybenzamide, Figure 5), a known blocker of $\mathrm{K}_{\text {ATP }}$ channels (also containing a type of SUR), induced a more potent inhibition of TRPM4-SUR1 coexpressed channels than of TRPM4 alone [17]. Intracellularly applied glibenclamide $(100 \mu \mathrm{M})$ greatly (by $78 \%)$ reduced TRPM4 expressed in HEK cells [9]. Even more potent inhibition was observed in HEK cells (10 $\mu \mathrm{M}$ glibenclamide, reduced to $7 \%$ of control) [20]. Glibenclamide, applied to the intracellular side at a concentration of $10 \mu \mathrm{M}$, reduced the open probability of native TRPM4 to approximately $20-30 \%$ of the control in human right atrial cells [4] and in the left ventricular cells of spontaneously hypertensive rats [27]. As low as $300 \mathrm{nM}$ glibenclamide blocked native TRPM4-SUR1 channels in human brain endothelial cells [21], while TRPM4 channels on detrusor smooth muscle cells were less sensitive (100 $\mu \mathrm{M}$ was used) [108]. Glibenclamide reduced both components of the transient outward $\mathrm{K}^{+}$current with an $\mathrm{IC}_{50}$ of $50 \mu \mathrm{M}$ in mouse ventricular myocytes [109]. At $100 \mu \mathrm{M}$, glibenclamide inhibited expressed CFTR channels [110] and several $\mathrm{Kv}$ channels in human atrial and ventricular myocytes [111]. Therefore, the low selectivity of glibenclamide makes its use unideal for studying TRPM4, especially in tissue containing $\mathrm{K}_{\text {ATP }}$ channels. Despite this, glibenclamide is still used in many studies to test the function of TRPM4, especially in relation to the nervous system [112]. 


\subsection{Clotrimazole}

The antimycotic drug clotrimazole (IUPAC name: 1-[(2-chlorophenyl)-diphenylmethyl] imidazole, Figure 4) blocked TRPM4, with an $\mathrm{IC}_{50}$ in the range of 1-10 $\mu \mathrm{M}$ [76]. Clotrimazole also reduced the TRPM2 current $\left(\mathrm{IC}_{50}\right.$ of $\left.0.7 \mu \mathrm{M}\right)$ in rat cardiac fibroblasts [113] and irreversibly blocked recombinant human TRPM2 expressed in HEK cells at $30 \mu \mathrm{M}$ [114]. Clotrimazole effectively inhibited intermediate-conductance $\mathrm{Ca}^{2+}$-activated $\mathrm{K}^{+}$channels [115] and the slow component of transient outward $\mathrm{K}^{+}$current in mouse ventricular cells [109] with $\mathrm{IC}_{50}$ values of approximately 0.15 and $8 \mu \mathrm{M}$, respectively. Similarly, 5, 25, and $50 \mu \mathrm{M}$ clotrimazole rapidly and mostly irreversibly inhibited the L-type $\mathrm{Ca}^{2+}$ current of guinea-pig ventricular cardiomyocytes by 16,59, and 93\%, respectively [116]. Clotrimazole reduced not only native L-type $\mathrm{Ca}^{2+}$ current but also recombinant human cardiac L-type $\mathrm{Ca}^{2+}$ channel $\alpha 1 C$ subunits stably expressed in HEK cells [117]. These findings make the use of clotrimazole as a TRPM4 inhibitor very unlikely.

\section{9. $D P C, D C D P C$, and $N P P B$}

Some aromatic compounds (Figure 4), such as DPC (diphenylamine-2-carboxylic acid, IUPAC name: 2-anilinobenzoic acid), DCDPC (3',5-Dichlorodiphenylamine-2-carboxylic acid, IUPAC name: 5-nitro-2-(3-phenylpropylamino)benzoic acid), and NPPB (IUPAC name: 5-nitro-2-(3-phenylpropylamino)benzoic acid), are known as blockers of chloride channels. These molecules blocked $\mathrm{Ca}^{2+}$-activated channels (being permeable to monovalent cations and usually referred to as $\mathrm{NSC}_{\mathrm{Ca}}$ before the discovery and characterization of TRPM4). This inhibition has been reported in various tissues, such as rat exocrine pancreatic cells [118], cochlear outer hair cells [119], and murine renal tubular cells [120]. At 10 and $100 \mu \mathrm{M}$, DCDPC reduced the open probability of $\mathrm{NSC}_{\mathrm{Ca}}$ to 43 and $17 \%$ of the control in murine renal tubules, respectively [120]. NPPB and DPC at a concentration of $100 \mu \mathrm{M}$ reduced $\mathrm{I}_{\left(\mathrm{NSC}_{\mathrm{Ca}}\right)}$ on the basolateral membrane of rat exocrine pancreatic cells (decreased the open probability from 0.5 in the control to 0.2 and 0.04 , respectively) [118]. Despite the inhibition of I(NSC $\left.\mathrm{Ca}_{\mathrm{a}}\right)$ by DPC, DCDPC, and NPPB, their chemical structures share little similarity with those of other TRPM4 blockers and are not used at all for TRPM4 inhibition.

\subsection{9-Phenanthrol}

One of the most widely used TRPM4 inhibitors is 9-phenanthrol (IUPAC name: phenanthren-9-ol, Figure 5). Grand et al. described 9-phenanthrol in 2008 [74], and six years later, a thorough review detailed the effects of 9-phenanthrol on both recombinant and endogenous TRPM4 channels [77]. Guinamard et al. discussed the specificity of the compound and summarized its actions on smooth muscle, on the heart, and on neuronal activity. The contribution of TRPM4 to cell death and angiogenesis was also discussed [77]. The $\mathrm{IC}_{50}$ of 9-phenanthrol was in the range of $17-20 \mu \mathrm{M}$ in both whole-cell and inside-out patch recordings, and its effect was reversible and voltage-independent [74]. Interestingly, a much smaller $\mathrm{IC}_{50}(1.7 \mathrm{nM})$ was reported in human adipose-derived stem cells, but the drug was used in pretreatment [121]. 9-Phenanthrol-induced TRPM4 inhibition was reversible, although removal of the inhibition was more difficult than with FFA [122]. 9-Phenanthrol reversibly reduced the duration of the action potential (AP) of murine atrial cells with an $\mathrm{IC}_{50}$ of $21 \mu \mathrm{M}$ [123]. TRPM4 channels in freshly isolated rat cerebral arterial smooth muscle cells were shown to be slightly more sensitive to 9-phenanthrol ( $\mathrm{IC}_{50}$ was $\left.11 \mu \mathrm{M}\right)$ [124]. Even $100 \mu \mathrm{M}$ 9-phenanthrol had no effect on TRPM5 [74]. On the contrary, 9-phenanthrol inhibited cAMP-dependent protein kinase and myosin light chain kinase of bovine heart with an $\mathrm{IC}_{50}$ of $10 \mu \mathrm{M}$ [125]. Although $10 \mu \mathrm{M}$ 9-phenanthrol did not alter the voltage-gated $\mathrm{Ca}^{2+}$ and $\mathrm{K}^{+}$channels of primary cardiomyocytes, at $100 \mu \mathrm{M}$, it induced 47 and $43 \%$ reductions in these channels, respectively [122]. In contrast, as low as 3-30 $\mu \mathrm{M}$ 9-phenanthrol significantly reduced several $\mathrm{K}^{+}$currents in native cardiomyocytes [126]. 9-Phenanthrol blocked cardiac sodium channels and dose-dependently inhibited late and peak sodium currents of rabbit ventricular cells with $\mathrm{IC}_{50}$ values of 18 and $71 \mu \mathrm{M}$, respectively [127]. Endothelial cell KCa3.1 channels were activated by $20 \mu \mathrm{M}$ 9-phenanthrol, presumably by 
direct channel activation [128]. 9-Phenanthrol blocked TMEM16A-induced currents in rat arterial smooth muscle myocytes with an $\mathrm{IC}_{50}$ of $12 \mu \mathrm{M}$ and modified channel gating, suggesting that it is not a pore blocker of TMEM16A [129]. Moreover, 9-phenanthrol autofluoresces at $340 \mathrm{~nm}$, which, however, at $10 \mu \mathrm{M}$, accounted for only $6 \mathrm{nM}$ of the intracellular $\mathrm{Ca}^{2+}$ level [105]. At $30 \mu \mathrm{M}, 9$-phenanthrol (if applied only from the intracellular side) inhibited human but activated murine TRPM4 channels stably overexpressed in human embryonal kidney (TsA-201) cells [130]. This must be kept in mind when 9-phenathrol is about to be used in mouse, as the compound might diffuse through the cell membrane due to its lipophilic nature. These results highlight the fact that although 9-phenanthrol is a good and potent TRPM4 inhibitor, it has effects on other channels. This must be taken into account upon its application, especially due to its narrow "therapeutic window".

\subsection{CBA and Other Related Compounds (LBA and NBA)}

Luckily, CBA (IUPAC name: 4-chloro-2-[[2-(2-chlorophenoxy)acetyl]amino]benzoic acid), a more potent drug with good selectivity, was recently developed [78]. CBA is commercially available and evokes a reversible and approximately 15 times stronger TRPM4 current inhibition compared with 9-phenanthrol. Moreover, CBA reduces endogenous TRPM4 currents even more effectively compared with expressed TRPM4 (IC ${ }_{50}$ values of 1.1 and $1.8 \mu \mathrm{M}$, respectively). In addition, even at $10 \mu \mathrm{M}$, where at least 90\% TRPM4 current inhibition was detected, CBA hardly influenced other important channels, such as TRPM5, GABA A receptor $\alpha 1$ subunit, NMDA receptor, or L-type calcium (judged by a reduction in specific antagonist binding only) [78]. The cardiac Kv11.1 (hERG) channel showed only $<5 \%$ inhibition of dofetilide binding in the presence of $10 \mu \mathrm{M} \mathrm{CBA}$. On the contrary, in canine left ventricular cells, $10 \mu \mathrm{M}$ CBA reduced transient outward $\mathrm{K}^{+}$and late $\mathrm{Na}^{+}$currents by 20 and 47\%, respectively [131]. Apart from being a TRPM4 blocker, CBA acts as a chemical chaperone that reduces TRPM4 degradation by the endoplasmic reticulum-associated process [78]. The effectivity of CBA was confirmed on the endogenous TRPM4 current of lymph node carcinoma of prostate (LNCaP) cells [132]. It must be noted that in contrast to the results of Ozhathil et al., the inhibition was only partially reversible; additionally, $20-30 \%$ of the TRPM 4 current remained even in the presence of $10 \mu \mathrm{M}$ CBA [132]. The reason for this discrepancy cannot be explained by a difference in cells, as both studies used LNCaP cells. In another prostate cancer cell line, human-derived DU145 cells, CBA was even less effective, as it reduced endogenous TRPM4 current by 55 and $65 \%$ at 3 and $50 \mu \mathrm{M}$, respectively [132]. Even more importantly, CBA affected TRPM4-influenced cellular functions (proliferation and migration) in these DU145 cells only in very high doses $(\geq 25 \mu \mathrm{M})$. CBA actions on cancer hallmark functions (cell viability, migration, cell cycle shift, and adhesion) seemed to be independent of TRPM4, as these processes were present in DU145 cells after the KO of TRPM4 [132]. Borgström et al. suggested the long-term treatment and/or the remaining TRPM4 current in the presence of high CBA doses as a potential reason for the TRPM4-independent toxic effects [132]. Indeed, the previously mentioned chemical chaperone action of CBA might be responsible and serve as an explanation.

In addition to CBA, two other compounds were described as potent TRPM4 inhibitors: NBA (IUPAC name: 4-chloro-2-(1-naphthyloxyacetamido)benzoic acid) and LBA (IUPAC name: 4-chloro-2-(2-(4-chloro-2-methylphenoxy)propanamido) benzoic acid) [78]. Compared to CBA, NBA and LBA were even more potent on TRPM4 channels expressed in HEK cells $\left(\mathrm{IC}_{50}\right.$ values were 0.4 and $1.6 \mu \mathrm{M}$, respectively). In the case of native TRPM4 channels, NBA was the most potent blocker, with an $\mathrm{IC}_{50}$ of $0.13 \mu \mathrm{M}$ in the HCT116 colorectal cancer cell line [133], while LBA was slightly less potent compared to CBA ( $\mathrm{IC}_{50}$ values of 1.84 and $1.17 \mu \mathrm{M}$, respectively). Regarding their specificity, $10 \mu \mathrm{M}$ NBA influenced glucagon-like peptide receptor 1 , while $10 \mu \mathrm{M}$ NBA slightly potentiated TRPM5 currents [78]. Although both NBA and LBA seemed to be slightly more potent blockers of endogenous TRPM4 currents in LNCaP cells, interestingly, neither was able to generate complete inhibition [132]. Both compounds exerted practically irreversible inhibition, and LBA was also less potent $\left(\mathrm{IC}_{50}\right.$ of $\left.0.7 \mu \mathrm{M}\right)$ in TRPM4 inhibition compared with NBA $\left(\mathrm{IC}_{50}\right.$ of $\left.0.2 \mu \mathrm{M}\right)$. At a concen- 
tration of $50 \mu \mathrm{M}, \mathrm{NBA}$ and LBA blocked approximately 90 and $85 \%$ of the endogenous TRPM4 currents in DU145 cells, but neither compound influenced the proliferation and migration of these cells [132]. HCT116 cells were more sensitive than LNCaP cells, as complete and irreversible TRPM4 inhibition could be achieved by all three drugs [133]. It seems that although CBA, NBA, and LBA are very potent inhibitors of TRPM4, their effect is less pronounced in cells that have endogenous TRPM4 channels than in those with overexpressed ones. Moreover, unlike with 9-phenanthrol, their inhibition did not lead to functional consequences. CBA and NBA were more effective than 9-phenanthrol and glibenclamide in preventing glutamate-induced neuronal cell death in vitro [134]. On the contrary, similar effectivity was reported in neurons, where membrane potential oscillations and the respiratory output were strongly reduced by both 9-phenanthrol $(30 \mu \mathrm{M})$ and CBA $(50 \mu \mathrm{M})$ in a comparable manner [135]. It must be noted that CBA was applied at a large concentration, and, as its selectivity is not thoroughly established yet, off-target effects could be involved. A recent study compared CBA, NBA, and 9-phenanthrol; NBA was the best, as it reduced stably overexpressed human and murine TRPM4 channels with similar effectivity ( $\mathrm{IC}_{50}$ values between 0.1 and $0.2 \mu \mathrm{M}$ ) upon extra- and intracellular application [130]. Surprisingly, CBA was not effective on murine TRPM4 channels, while it blocked human TRPM4 with $\mathrm{IC}_{50}$ values of 0.7 and $0.8 \mu \mathrm{M}$ when applied extra- and intracellularly, respectively. Comparing the cytotoxicity of the three drugs, NBA and CBA possessed similar $\mathrm{IC}_{50}$ values (332 and $545 \mu \mathrm{M}$, respectively), but 9-phenanthrol was much more toxic $\left(\mathrm{IC}_{50}\right.$ of $\left.20 \mu \mathrm{M}\right)$, at least in non-TRPM4 transfected TsA-201 cells [130]. Clearly, more studies are required to determine the use of CBA, NBA, and LBA in the research of TRPM4 functions.

\subsection{M4P, M4M, and M4M1 Anti-TRPM4 Antibodies}

Due to the absence of an ideal (potent, selective, and able to act when applied in vivo) TRPM4 inhibitor, Chen et al. reported another approach for the evaluation of the (patho)physiological role of TRPM4 by the generation of M4P [80]. This antibody binds to a region close to the channel pore and is capable of inhibiting TRPM4 current and downregulating TRPM4 surface expression. Furthermore, M4P can also be used in vivo by intravenous injection. In a rat cerebral ischemia-reperfusion model, M4P attenuated cerebral injury on both histological and functional levels by reducing the increase in TRPM4 expression [80]. M4P exerted an anti-oncotic effect on various cell types within the brain, including neurons, astrocytes, and vascular endothelial cells [136]. M4P was selective for TRPM4, as it did not influence either TRPM5 [80] or TRPM2 and TRPM7 channels [136]. Recently, Low et al. developed two mouse monoclonal antibodies (M4M and M4M1) targeting an extracellular epitope of human TRPM4 [81]. Interestingly, these antibodies reduced ion currents mediated by expressed human TRPM4 channels but failed to be effective in vivo in rats, highlighting the specificity of TRPM4 inhibition by these truly selective antibodies.

\subsection{3. siRNA Approach}

Due to the absence of a highly specific pharmacological TRPM4 inhibitor, other approaches are used to study the function of TRPM4. Small interfering RNAs (siRNA) are short (19-30 base pairs long) double-stranded RNA sequences and have been used for a long time to investigate protein functions by reducing their expression, which is achieved by the posttranscriptional silencing action of siRNA $[137,138]$. TRPM4 silencing was used both in vitro $[139,140]$ and in vivo $[141,142]$. The application of specific TRPM4 siRNA is compared, in many cases, with the effect of pharmacological inhibition and with the effect of a negative control siRNA (a scrambled sequence that cannot bind to any known sequence). The effectivity of silencing by siRNA is usually tested at least at the mRNA and, in many cases, also at the protein level. In the case of TRPM4 silencing, this effectivity was nearly complete in cells (about $80 \%$ of the cells in the treated cerebral arteries) in which the uptake of siRNA occurred (in the remaining $20 \%$ of cells, siRNA treatment did not change the TRPM4 expression) [139]. Similarly, the reduction in TRPM4 protein was approximately 
$70 \%$ in rat posterior cerebral artery segments [143]. In other studies where cell cultures were treated with siRNA, the quantity of TRPM4 at both mRNA and protein levels was 20\% of the nontreated cells (and also cells treated with the scrambled sequence) [140]. TRPM4 mRNA was reduced by $50-75 \%$ with siRNA treatment in two prostate cancer cell lines (DU145 and LNCaP) [144], and 75\% reduction in mRNA and approximately $50 \%$ reduction in TRPM4 protein was achieved in human umbilical vein endothelial cells (HUVEC) [145] and leukemia cell lines with the MLL gene rearrangement [146]. In addition, siRNA not only reduced TRPM4 expression but also effectively prevented the expression of TRPM4 upon in vivo application in permanent middle cerebral artery [141] and bilateral common carotid arteries occlusion rat models [142]. None of the previous studies reported nonspecific actions of the siRNA treatment; no other proteins (and/or their mRNA), including other TRP channels such as TRPC3, TRPC6 [139], and TRPM7 [140], were influenced by the siRNA treatment targeting TRPM4. This was the case for all of the players of the store-operated calcium entry (ORAI1, ORAI2, ORAI3, STIM1, and STIM2) as well [144]. Table 1 lists studies using siRNA for TRPM4 silencing.

Table 1. Functional evaluation of TRPM4 using siRNA-mediated silencing.

\begin{tabular}{|c|c|c|c|}
\hline Studied Preparation & Results & Conclusion & Reference \\
\hline Rat cerebral arteries & $80 \%$ reduction in TRPM 4 mRNA & $\begin{array}{l}\text { TRPM4 channels are regulated by } \\
\mathrm{Ca}^{2+} \text { release from IP3 receptor }\end{array}$ & [139] \\
\hline $\begin{array}{l}\text { Rat posterior cerebral } \\
\text { artery segments }\end{array}$ & $70 \%$ reduction in TRPM 4 mRNA & $\begin{array}{l}\text { Epithelial sodium channels and } \\
\text { TRPM4 interact and contribute to } \\
\text { pressure-induced vasoconstriction }\end{array}$ & [143] \\
\hline Prostate cancer cell lines & $\begin{array}{l}50-75 \% \text { reduction in } \\
\text { TRPM4 mRNA }\end{array}$ & $\begin{array}{l}\text { TRPM4 contributes to cancer } \\
\text { cell migration }\end{array}$ & [144] \\
\hline $\begin{array}{l}\text { Human umbilical vein } \\
\text { endothelial cells (HUVEC) }\end{array}$ & $\begin{array}{l}75 \% \text { reduction in TRPM } 4 \text { mRNA } \\
\text { and } \sim 50 \% \text { reduction in } \\
\text { TRPM } 4 \text { protein }\end{array}$ & $\begin{array}{l}\text { TRPM4 is involved in endothelial } \\
\text { injury induced by arsenic trioxide }\end{array}$ & [145] \\
\hline $\begin{array}{l}\text { Leukemia cell lines with the MLL } \\
\text { gene rearrangement }\end{array}$ & $\begin{array}{c}75 \% \text { reduction in TRPM } 4 \text { mRNA } \\
\text { and } \sim 50 \% \text { reduction in } \\
\text { TRPM } 4 \text { protein }\end{array}$ & $\begin{array}{l}\text { TRPM4 may be involved in the } \\
\text { pathogenesis of } \\
\text { MLL-rearranged leukemia }\end{array}$ & [146] \\
\hline $\begin{array}{l}\text { Permanent middle cerebral artery } \\
\text { of rat }\end{array}$ & $\begin{array}{c}\text { Prevented the expression } \\
\text { of TRPM4 }\end{array}$ & $\begin{array}{c}\text { TRPM4 upregulation contributes } \\
\text { to cerebral damage in acute phase } \\
\text { of stroke }\end{array}$ & [141] \\
\hline $\begin{array}{l}\text { Bilateral common carotid arteries } \\
\text { occlusion rat models }\end{array}$ & $\begin{array}{l}\text { Prevented the expression } \\
\text { of TRPM4 }\end{array}$ & $\begin{array}{l}\text { TRPM4 mediates cognitive } \\
\text { deficits and LTP impairment and } \\
\text { reduces the expression of } \\
\text { synaptic proteins }\end{array}$ & [142] \\
\hline HUVEC & $\begin{array}{l}\text { At least } 90 \% \text { reduction in TRPM4 } \\
\text { mRNA and protein }\end{array}$ & $\begin{array}{l}\text { TRPM4 is involved in } \\
\text { lipopolysaccharide-induced } \\
\text { endothelial cell death }\end{array}$ & [140] \\
\hline Jurkat cells & $\begin{array}{c}\text { Some reduction in TRPM4 mRNA } \\
\text { and protein }\end{array}$ & $\begin{array}{l}\text { TRPM4-mediated depolarization } \\
\text { modulates } \mathrm{Ca}^{2+} \text { oscillations }\end{array}$ & [147] \\
\hline
\end{tabular}

\subsection{Dominant-Negative Splice Variants}

Another approach to study the role of TRPM4 is to reduce its function by expressing a splice variant, which blocks the wild-type variant. Two variants are available in reports. One was first described in HEK cells, in which a single amino acid modification (D984A) led to nonconducting channels [148]. Stable overexpression of the D984A dominant-negative TRPM4 splice variant in the colorectal cancer cell line HCT116 resulted in the complete inhibition of the current without a reduction in TRPM4 protein expression [24]. Similarly, no current could be detected upon overexpression of the D984A dominant-negative TRPM4 splice variant in a human prostate cancer cell line (DU145 cells) [132]. 
The second mutant lacks the first 177 amino acids in the N-terminus ( $\triangle \mathrm{N}-\mathrm{TRPM} 4)$ and hardly conducts any current in Jurkat cells [147]. Using $\triangle \mathrm{N}-\mathrm{TRPM} 4$, the TRPM4 channels are present on the cell membrane but fail to conduct ions. Similar to the effect of siRNA-mediated TRPM4 silencing, $\triangle$ N-TRPM4 expression reduced lipopolysaccharideinduced endothelial cell death [140]. TRPM4-mediated current was greatly reduced in the rat insulinoma cell line INS-1 expressing the $\triangle \mathrm{N}-\mathrm{TRPM} 4$ variant, and glucose- or arginine-vasopressin-induced insulin secretion was also lower [25]. Moreover, in the same cell line, the $\triangle \mathrm{N}$-TRPM4 variant abolished calcium signals and insulin secretion, while another TRPM4 construct lacking the last 160 amino acids in the C-terminal region $(\Delta C$ TRPM4, not suppressing the channel function) failed to influence calcium signals and insulin secretion [149]. Table 2 shows studies applying TRPM4 dominant-negative variants.

Table 2. Studies with TRPM4 dominant-negative variants.

\begin{tabular}{|c|c|c|c|c|}
\hline Type of Variant & Studied Preparation & Results & Conclusion & Reference \\
\hline $\begin{array}{c}\text { Single amino acid } \\
\text { modification (D984A) }\end{array}$ & HEK cells & $\begin{array}{l}\text { Nonconducting } \\
\text { TRPM4 channels }\end{array}$ & $\begin{array}{l}\text { Information about the selectivity } \\
\text { filter of TRPM4 }\end{array}$ & {$[148]$} \\
\hline D984A variant & $\begin{array}{l}\text { Colorectal cancer cell } \\
\text { line HCT116 }\end{array}$ & $\begin{array}{l}\text { Complete inhibition } \\
\text { of the current without } \\
\text { the reduction in } \\
\text { TRPM4 } \\
\text { protein expression }\end{array}$ & $\begin{array}{c}\text { Ion conduction of TRPM4 plays } \\
\text { a versatile role in cancer cell } \\
\text { proliferation, cell cycle, } \\
\text { and invasion }\end{array}$ & {$[24]$} \\
\hline D984A variant & $\begin{array}{l}\text { Human prostate } \\
\text { cancer cells line }\end{array}$ & $\begin{array}{l}\text { Nonconducting } \\
\text { TRPM4 channels }\end{array}$ & $\begin{array}{l}\text { TRPM4 is involved in cancer } \\
\text { hallmark functions (cell viability, } \\
\text { proliferation, migration, and cell } \\
\text { cycle shift) }\end{array}$ & {$[132]$} \\
\hline $\begin{array}{l}\text { Deletion of first } 177 \text { amino } \\
\text { acids in the } \mathrm{N} \text {-terminus } \\
\qquad(\Delta \mathrm{N}-\mathrm{TRPM})\end{array}$ & Jurkat cells & $\begin{array}{l}\text { Hardly conducts } \\
\text { any current }\end{array}$ & $\begin{array}{l}\text { TRPM4-mediated depolarization } \\
\text { modulates } \mathrm{Ca}^{2+} \text { oscillations }\end{array}$ & {$[147]$} \\
\hline$\Delta \mathrm{N}-\mathrm{TRPM} 4$ & HUVEC & $\begin{array}{l}\text { Suppression of } \\
\text { TRPM4 activity }\end{array}$ & $\begin{array}{l}\text { TRPM4 contributes to } \\
\text { lipopolysaccharide-induced } \\
\text { endothelial cell death }\end{array}$ & {$[140]$} \\
\hline$\Delta \mathrm{N}-\mathrm{TRPM} 4$ & $\begin{array}{l}\text { Rat insulinoma cell } \\
\text { line INS-1 }\end{array}$ & $\begin{array}{l}\text { Reduced TRPM4- } \\
\text { mediated current }\end{array}$ & $\begin{array}{l}\text { TRPM4 is involved in glucose- } \\
\text { or arginine-vasopressin-induced } \\
\text { insulin secretion }\end{array}$ & [25] \\
\hline$\Delta \mathrm{N}-\mathrm{TRPM} 4$ & $\begin{array}{l}\text { Rat insulinoma cell } \\
\text { line INS-1 }\end{array}$ & $\begin{array}{l}\text { Reduced TRPM4- } \\
\text { mediated current }\end{array}$ & $\begin{array}{l}\text { TRPM4 contributes to calcium } \\
\text { signals and insulin secretion }\end{array}$ & [149] \\
\hline
\end{tabular}

\section{Conclusions}

Although TRPM4 was first described at the beginning of the 21st century, reports about a $\mathrm{Ca}^{2+}$-activated nonspecific cationic current in various tissues were published long before that. Since then, a tremendous amount of knowledge has been accumulated, but there are still problems to be solved. For instance, the currently used inhibitors are still not selective enough; therefore, new approaches are being developed to circumvent selectivity issues. Therefore, currently, some use the silencing of TRPM4 expression and/or function to elucidate the role of TRPM4. These molecular biological approaches seem to be more specific at the moment, but their application is more complicated compared to using activator or inhibitor compounds. Nevertheless, TRPM4 has become a promising therapeutic target in central nervous system injuries and might also be involved in treatments of other conditions in the future.

Author Contributions: Conceptualization, N.S. and P.P.N.; writing-original draft preparation, C.D., T.H. and Z.M.K.; writing-review and editing, J.A., J.M. and T.B.; supervision, P.P.N. and N.S.; funding acquisition, P.P.N. and B.H. All authors have read and agreed to the published version of the manuscript. 
Funding: This work was funded by the National Research Development and Innovation Office (NKFIH-K115397 to P.P.N. and N.S.; NKFIH-K138090 to C.D., T.H., P.P.N., and N.S.; and NKFIHFK128116 to B.H.). Further support was provided by GINOP-2.3.2-15-2016-00040 and EFOP-3.6.216-2017-00006 (to P.P.N.), which are co-financed by the European Union and the European Regional Development Fund. Support was also obtained from the Thematic Excellence Program of the Ministry for Innovation and Technology in Hungary (TKP-2020-NKA-04) within the framework of the Space Sciences thematic program of the University of Debrecen. C.D. and T.H. were supported by the EFOP-3.6.3-VEKOP-16-2017-00009 project co-financed by the EU and the European Social Fund. C.D. and T.H. were supported by the ÚNKP-21-3 and ÚNKP-20-2 New National Excellence Program of the Ministry for Innovation and Technology from the National Research Development and Innovation Fund, respectively. Funding sources had no involvement in the preparation of the article; in the study design; in the collection, analysis, and interpretation of data; in writing of the report; or in the decision to submit the article for publication.

Institutional Review Board Statement: Not applicable.

Informed Consent Statement: Not applicable.

Data Availability Statement: Data sharing not applicable.

Conflicts of Interest: The authors declare no conflict of interest.

\section{Abbreviations}

\begin{tabular}{|c|c|}
\hline $\mathrm{AP}$ & action potential \\
\hline ATP & adenosine triphosphate \\
\hline BTP2 & 3,5-bis(trifluoromethyl)pyrazole derivative \\
\hline CBA & 4-chloro-2-[[2-(2-chlorophenoxy)acetyl]amino]benzoic acid \\
\hline CFTR & cystic fibrosis transmembrane conductance regulator \\
\hline $\mathrm{CHO}$ & Chinese hamster ovary \\
\hline DCDPC & $3^{\prime}, 5$-dichlorodiphenylamine-2-carboxylic acid \\
\hline $\mathrm{DPC}$ & diphenylamine-2-carboxylic acid \\
\hline DV & decavanadate \\
\hline $\mathrm{EC}_{50}$ & half effective activator concentration \\
\hline FFA & flufenamic acid \\
\hline HEK & human embryonic kidney \\
\hline HUVEC & human umbilical vein endothelial cells \\
\hline $\mathrm{IC}_{50}$ & half inhibitory concentration \\
\hline IP3 & inositol 1,4,5-trisphosphate \\
\hline $\mathrm{I}\left(\mathrm{NSC}_{\mathrm{Ca}}\right)$ & $\mathrm{Ca}^{2+}$-activated nonspecific cationic current \\
\hline $\mathrm{K}_{\mathrm{ATP}}$ & adenosine triphosphate-dependent $\mathrm{K}^{+}$ \\
\hline KCax.x & $\mathrm{Ca}^{2+}$-activated $\mathrm{K}^{+}$channels type $x . \mathrm{x}$ \\
\hline Kirx.x & inward rectifier $\mathrm{K}^{+}$channel type $\mathrm{x} . \mathrm{x}$ \\
\hline KD & knock-down \\
\hline $\mathrm{KO}$ & knock-out \\
\hline LBA & 4-chloro-2-(2-(4-chloro-2-methylphenoxy)propanamido) benzoic acid \\
\hline LNCaP & lymph node carcinoma of the prostate \\
\hline NBA & 4-chloro-2-(1-naphthyloxyacetamido)benzoic acid \\
\hline NMDA & N-methyl-D-aspartic acid \\
\hline $\mathrm{NO}$ & nitric oxide \\
\hline NPPB & 5-nitro-2-(3-phenylpropylamino)benzoic acid \\
\hline $\mathrm{NSC}_{\mathrm{Ca}}$ & $\mathrm{Ca}^{2+}$-activated nonspecific cationic channel \\
\hline PIP2 & phosphatidylinositol 4,5-bisphosphate \\
\hline PKC & protein kinase $\mathrm{C}$ \\
\hline PLC & phospholipase C \\
\hline PMA & phorbol 12-myristate 13 -acetate \\
\hline
\end{tabular}




$\begin{array}{ll}\text { tPA } & \text { tissue plasminogen activator } \\ \text { SiRNA } & \text { small interfering RNA } \\ \text { SUR1 } & \text { sulfonylurea receptor 1 } \\ \text { TRP } & \text { transient receptor potential } \\ \text { TRPA } & \text { transient receptor potential ankyrin } \\ \text { TRPC } & \text { transient receptor potential canonical } \\ \text { TRPM } & \text { transient receptor potential melastatin } \\ \text { TRPML } & \text { transient receptor potential mucolipin } \\ \text { TRPP } & \text { transient receptor potential polycystin } \\ \text { TRPV } & \text { transient receptor potential vanilloid }\end{array}$

\section{References}

1. Montell, C.; Rubin, G.M. Molecular characterization of the Drosophila trp locus: A putative integral membrane protein required for phototransduction. Neuron 1989, 2, 1313-1323. [CrossRef]

2. Chang, Y.; Schlenstedt, G.; Flockerzi, V.; Beck, A. Properties of the intracellular transient receptor potential (TRP) channel in yeast, Yvc1. FEBS Lett. 2010, 584, 2028-2032. [CrossRef]

3. Jimenez, I.; Prado, Y.; Marchant, F.; Otero, C.; Eltit, F.; Cabello-Verrugio, C.; Cerda, O.; Simon, F. TRPM Channels in Human Diseases. Cells 2020, 9, 2604. [CrossRef] [PubMed]

4. Guinamard, R.; Chatelier, A.; Demion, M.; Potreau, D.; Patri, S.; Rahmati, M.; Bois, P. Functional characterization of a Ca ${ }^{2+}$ activated non-selective cation channel in human atrial cardiomyocytes. J. Physiol. 2004, 558, 75-83. [CrossRef]

5. Guinamard, R.; Sallé, L.; Simard, C. The non-selective monovalent cationic channels TRPM4 and TRPM5. Adv. Exp. Med. Biol. 2011, 704, 147-171. [CrossRef] [PubMed]

6. Xu, X.Z.; Moebius, F.; Gill, D.L.; Montell, C. Regulation of melastatin, a TRP-related protein, through interaction with a cytoplasmic isoform. Proc. Natl. Acad. Sci. USA 2001, 98, 10692-10697. [CrossRef] [PubMed]

7. Launay, P.; Fleig, A.; Perraud, A.L.; Scharenberg, A.M.; Penner, R.; Kinet, J.P. TRPM4 is a Ca ${ }^{2+}$-activated nonselective cation channel mediating cell membrane depolarization. Cell 2002, 109, 397-407. [CrossRef]

8. Ullrich, N.D.; Voets, T.; Prenen, J.; Vennekens, R.; Talavera, K.; Droogmans, G.; Nilius, B. Comparison of functional properties of the $\mathrm{Ca}^{2+}$-activated cation channels TRPM4 and TRPM5 from mice. Cell Calcium 2005, 37, 267-278. [CrossRef]

9. Demion, M.; Bois, P.; Launay, P.; Guinamard, R. TRPM4, a Ca ${ }^{2+}$-activated nonselective cation channel in mouse sino-atrial node cells. Cardiovasc. Res. 2007, 73, 531-538. [CrossRef]

10. Demion, M.; Thireau, J.; Gueffier, M.; Finan, A.; Khoueiry, Z.; Cassan, C.; Serafini, N.; Aimond, F.; Granier, M.; Pasquié, J.L.; et al. Trpm4 gene invalidation leads to cardiac hypertrophy and electrophysiological alterations. PLoS ONE 2014, 9, e115256. [CrossRef]

11. Nilius, B.; Prenen, J.; Tang, J.; Wang, C.; Owsianik, G.; Janssens, A.; Voets, T.; Zhu, M.X. Regulation of the Ca ${ }^{2+}$ sensitivity of the nonselective cation channel TRPM4. J. Biol. Chem. 2005, 280, 6423-6433. [CrossRef]

12. Bouchghoul, H.; Bouyer, J.; Senat, M.V.; Mandelbrot, L.; Letourneau, A.; Bourcigaux, N.; Becquemont, L.; Verstuyft, C. Hypoglycemia and glycemic control with glyburide in women with gestational diabetes and genetic variants of cytochrome P450 $2 \mathrm{C} 9$ and/or OATP1B3. Clin. Pharmacol. Ther. 2020, 110, 141-148. [CrossRef]

13. Medert, R.; Pironet, A.; Bacmeister, L.; Segin, S.; Londono, J.E.C.; Vennekens, R.; Freichel, M. Genetic background influences expression and function of the cation channel TRPM4 in the mouse heart. Basic Res. Cardiol. 2020, 115, 70. [CrossRef]

14. Medert, R.; Jungmann, A.; Hildebrand, S.; Busch, M.; Grimm, D.; Flockerzi, V.; Müller, O.J.; Most, P.; Schumacher, D.; Freichel, M. Development of an AAV9-RNAi-mediated silencing strategy to abrogate TRPM4 expression in the adult heart. Pflugers Arch. 2021, 473, 533-546. [CrossRef]

15. Nilius, B.; Mahieu, F.; Prenen, J.; Janssens, A.; Owsianik, G.; Vennekens, R.; Voets, T. The Ca ${ }^{2+}$-activated cation channel TRPM4 is regulated by phosphatidylinositol 4,5-biphosphate. EMBO J. 2006, 25, 467-478. [CrossRef]

16. Zhang, Z.; Okawa, H.; Wang, Y.; Liman, E.R. Phosphatidylinositol 4,5-bisphosphate rescues TRPM4 channels from desensitization. J. Biol. Chem. 2005, 280, 39185-39192. [CrossRef]

17. Woo, S.K.; Kwon, M.S.; Ivanov, A.; Gerzanich, V.; Simard, J.M. The sulfonylurea receptor 1 (Sur1)-transient receptor potential melastatin 4 (Trpm4) channel. J. Biol. Chem. 2013, 288, 3655-3667. [CrossRef]

18. Nilius, B.; Prenen, J.; Janssens, A.; Voets, T.; Droogmans, G. Decavanadate modulates gating of TRPM4 cation channels. J. Physiol. 2004, 560, 753-765. [CrossRef]

19. Takezawa, R.; Cheng, H.; Beck, A.; Ishikawa, J.; Launay, P.; Kubota, H.; Kinet, J.P.; Fleig, A.; Yamada, T.; Penner, R. A pyrazole derivative potently inhibits lymphocyte $\mathrm{Ca}^{2+}$ influx and cytokine production by facilitating transient receptor potential melastatin 4 channel activity. Mol. Pharmacol. 2006, 69, 1413-1420. [CrossRef]

20. Simon, F.; Leiva-Salcedo, E.; Armisén, R.; Riveros, A.; Cerda, O.; Varela, D.; Eguiguren, A.L.; Olivero, P.; Stutzin, A. Hydrogen peroxide removes TRPM4 current desensitization conferring increased vulnerability to necrotic cell death. J. Biol. Chem. 2010, 285, 37150-37158. [CrossRef]

21. Gerzanich, V.; Kwon, M.S.; Woo, S.K.; Ivanov, A.; Simard, J.M. SUR1-TRPM4 channel activation and phasic secretion of MMP-9 induced by tPA in brain endothelial cells. PLoS ONE 2018, 13, e0195526. [CrossRef] [PubMed] 
22. Leitner, M.G.; Michel, N.; Behrendt, M.; Dierich, M.; Dembla, S.; Wilke, B.U.; Konrad, M.; Lindner, M.; Oberwinkler, J.; Oliver D. Direct modulation of TRPM4 and TRPM3 channels by the phospholipase C inhibitor U73122. Br. J. Pharmacol. 2016, 173, 2555-2569. [CrossRef] [PubMed]

23. Ngoc Tran, T.D.; Stovall, K.E.; Suantawee, T.; Hu, Y.; Yao, S.; Yang, L.J.; Adisakwattana, S.; Cheng, H. Transient receptor potential melastatin 4 channel is required for rat dental pulp stem cell proliferation and survival. Cell Prolif. 2017, 50. [CrossRef]

24. Kappel, S.; Stokłosa, P.; Hauert, B.; Ross-Kaschitza, D.; Borgström, A.; Baur, R.; Galván, J.A.; Zlobec, I.; Peinelt, C. TRPM4 is highly expressed in human colorectal tumor buds and contributes to proliferation, cell cycle, and invasion of colorectal cancer cells. Mol. Oncol. 2019, 13, 2393-2405. [CrossRef] [PubMed]

25. Cheng, H.; Beck, A.; Launay, P.; Gross, S.A.; Stokes, A.J.; Kinet, J.P.; Fleig, A.; Penner, R. TRPM4 controls insulin secretion in pancreatic beta-cells. Cell Calcium 2007, 41, 51-61. [CrossRef] [PubMed]

26. Gonzales, A.L.; Earley, S. Endogenous cytosolic $\mathrm{Ca}^{2+}$ buffering is necessary for TRPM4 activity in cerebral artery smooth muscle cells. Cell Calcium 2012, 51, 82-93. [CrossRef] [PubMed]

27. Guinamard, R.; Demion, M.; Magaud, C.; Potreau, D.; Bois, P. Functional expression of the TRPM4 cationic current in ventricular cardiomyocytes from spontaneously hypertensive rats. Hypertension 2006, 48, 587-594. [CrossRef]

28. Yarishkin, O.V.; Hwang, E.M.; Park, J.Y.; Kang, D.; Han, J.; Hong, S.G. Endogenous TRPM4-like channel in Chinese hamster ovary (CHO) cells. Biochem. Biophys. Res. Commun. 2008, 369, 712-717. [CrossRef]

29. Autzen, H.E.; Myasnikov, A.G.; Campbell, M.G.; Asarnow, D.; Julius, D.; Cheng, Y. Structure of the human TRPM4 ion channel in a lipid nanodisc. Science 2018, 359, 228-232. [CrossRef]

30. Huang, Y.; Fliegert, R.; Guse, A.H.; Lü, W.; Du, J. A structural overview of the ion channels of the TRPM family. Cell Calcium 2020, 85, 102111. [CrossRef]

31. Yamaguchi, S.; Tanimoto, A.; Iwasa, S.; Otsuguro, K. TRPM4 and TRPM5 Channels Share Crucial Amino Acid Residues for Ca. Int. J. Mol. Sci. 2019, 20, 2012. [CrossRef]

32. Constantine, M.; Liew, C.K.; Lo, V.; Macmillan, A.; Cranfield, C.G.; Sunde, M.; Whan, R.; Graham, R.M.; Martinac, B Heterologously-expressed and Liposome-reconstituted Human Transient Receptor Potential Melastatin 4 Channel (TRPM4) is a Functional Tetramer. Sci. Rep. 2016, 6, 19352. [CrossRef]

33. Rivas, J.; Díaz, N.; Silva, I.; Morales, D.; Lavanderos, B.; Álvarez, A.; Saldías, M.P.; Pulgar, E.; Cruz, P.; Maureira, D.; et al. KCTD5, a novel TRPM4-regulatory protein required for cell migration as a new predictor for breast cancer prognosis. FASEB J. 2020, 34, 7847-7865. [CrossRef]

34. Li, Y.; Brayden, J.E. Rho kinase activity governs arteriolar myogenic depolarization. J. Cereb. Blood Flow Metab. 2017, 37, 140-152. [CrossRef]

35. Flannery, R.J.; Kleene, N.K.; Kleene, S.J. A TRPM4-dependent current in murine renal primary cilia. Am. J. Physiol. Renal Physiol. 2015, 309, F697-F707. [CrossRef]

36. Cai, Y.X.; Zhang, B.L.; Yu, M.; Yang, Y.C.; Ao, X.; Zhu, D.; Wang, Q.S.; Lou, J.; Liang, C.; Tang, L.L.; et al. Cholesterol Stimulates the Transient Receptor Potential Melastatin 4 Channel in mpkCCD c14 Cells. Front. Pharmacol. 2021, 12, 627875. [CrossRef]

37. Bousova, K.; Jirku, M.; Bumba, L.; Bednarova, L.; Sulc, M.; Franek, M.; Vyklicky, L.; Vondrasek, J.; Teisinger, J. PIP2 and PIP3 interact with N-terminus region of TRPM4 channel. Biophys. Chem. 2015, 205, 24-32. [CrossRef]

38. Bousova, K.; Barvik, I.; Herman, P.; Hofbauerová, K.; Monincova, L.; Majer, P.; Zouharova, M.; Vetyskova, V.; Postulkova, K.; Vondrasek, J. Mapping of CaM, S100A1 and PIP2-Binding Epitopes in the Intracellular N- and C-Termini of TRPM4. Int. J. Mol. Sci. 2020, 21, 4323. [CrossRef]

39. Chuang, H.H.; Prescott, E.D.; Kong, H.; Shields, S.; Jordt, S.E.; Basbaum, A.I.; Chao, M.V.; Julius, D. Bradykinin and nerve growth factor release the capsaicin receptor from PtdIns(4,5)P2-mediated inhibition. Nature 2001, 411, 957-962. [CrossRef]

40. Liu, D.; Liman, E.R. Intracellular $\mathrm{Ca}^{2+}$ and the phospholipid PIP2 regulate the taste transduction ion channel TRPM5. Proc. Natl. Acad. Sci. USA 2003, 100, 15160-15165. [CrossRef]

41. Runnels, L.W.; Yue, L.; Clapham, D.E. The TRPM7 channel is inactivated by PIP(2) hydrolysis. Nat. Cell Biol. 2002, 4, 329-336. [CrossRef] [PubMed]

42. Liu, B.; Qin, F. Functional control of cold- and menthol-sensitive TRPM8 ion channels by phosphatidylinositol 4,5-bisphosphate. J. Neurosci. 2005, 25, 1674-1681. [CrossRef] [PubMed]

43. Rohács, T.; Lopes, C.M.; Michailidis, I.; Logothetis, D.E. PI(4,5)P2 regulates the activation and desensitization of TRPM8 channels through the TRP domain. Nat. Neurosci. 2005, 8, 626-634. [CrossRef] [PubMed]

44. Lee, J.; Cha, S.K.; Sun, T.J.; Huang, C.L. PIP2 activates TRPV5 and releases its inhibition by intracellular Mg ${ }^{2+}$. J. Gen. Physiol. 2005, 126, 439-451. [CrossRef]

45. Lopes, C.M.; Rohács, T.; Czirják, G.; Balla, T.; Enyedi, P.; Logothetis, D.E. PIP2 hydrolysis underlies agonist-induced inhibition and regulates voltage gating of two-pore domain $\mathrm{K}^{+}$channels. J. Physiol. 2005, 564, 117-129. [CrossRef]

46. Wu, L.; Bauer, C.S.; Zhen, X.G.; Xie, C.; Yang, J. Dual regulation of voltage-gated calcium channels by PtdIns(4,5)P2. Nature 2002, 419, 947-952. [CrossRef]

47. Gamper, N.; Reznikov, V.; Yamada, Y.; Yang, J.; Shapiro, M.S. Phosphatidylinositol [correction] 4,5-bisphosphate signals underlie receptor-specific Gq/11-mediated modulation of N-type $\mathrm{Ca}^{2+}$ channels. J. Neurosci. 2004, 24, 10980-10992. [CrossRef]

48. Hille, B.; Dickson, E.J.; Kruse, M.; Vivas, O.; Suh, B.C. Phosphoinositides regulate ion channels. Biochim. Biophys. Acta 2015, 1851, 844-856. [CrossRef] 
49. Winkler, P.A.; Huang, Y.; Sun, W.; Du, J.; Lü, W. Electron cryo-microscopy structure of a human TRPM4 channel. Nature 2017, 552, 200-204. [CrossRef]

50. Michel, A.D.; Xing, M.; Thompson, K.M.; Jones, C.A.; Humphrey, P.P. Decavanadate, a P2X receptor antagonist, and its use to study ligand interactions with P2X7 receptors. Eur. J. Pharmacol. 2006, 534, 19-29. [CrossRef]

51. Föhr, K.J.; Wahl, Y.; Engling, R.; Kemmer, T.P.; Gratzl, M. Decavanadate displaces inositol 1,4,5-trisphosphate (IP3) from its receptor and inhibits IP3 induced $\mathrm{Ca}^{2+}$ release in permeabilized pancreatic acinar cells. Cell Calcium 1991, 12, 735-742. [CrossRef]

52. Aureliano, M. Vanadate oligomer inhibition of passive and active $\mathrm{Ca}^{2+}$ translocation by the $\mathrm{Ca}^{2+}$ pump of sarcoplasmic reticulum. J. Inorg. Biochem. 2000, 80, 145-147. [CrossRef]

53. Zhang, X.; Xin, P.; Yoast, R.E.; Emrich, S.M.; Johnson, M.T.; Pathak, T.; Benson, J.C.; Azimi, I.; Gill, D.L.; Monteith, G.R.; et al. Distinct pharmacological profiles of ORAI1, ORAI2, and ORAI3 channels. Cell Calcium 2020, 91, 102281. [CrossRef]

54. He, L.P.; Hewavitharana, T.; Soboloff, J.; Spassova, M.A.; Gill, D.L. A functional link between store-operated and TRPC channels revealed by the 3,5-bis(trifluoromethyl)pyrazole derivative, BTP2. J. Biol. Chem. 2005, 280, 10997-11006. [CrossRef]

55. Piao, H.; Takahashi, K.; Yamaguchi, Y.; Wang, C.; Liu, K.; Naruse, K. Transient receptor potential melastatin-4 is involved in hypoxia-reoxygenation injury in the cardiomyocytes. PLoS ONE 2015, 10, e0121703. [CrossRef]

56. Sarmiento, D.; Montorfano, I.; Cerda, O.; Cáceres, M.; Becerra, A.; Cabello-Verrugio, C.; Elorza, A.A.; Riedel, C.; Tapia, P.; Velásquez, L.A.; et al. Increases in reactive oxygen species enhance vascular endothelial cell migration through a mechanism dependent on the transient receptor potential melastatin 4 ion channel. Microvasc. Res. 2015, 98, 187-196. [CrossRef]

57. Ding, X.Q.; Ban, T.; Liu, Z.Y.; Lou, J.; Tang, L.L.; Wang, J.X.; Chu, W.F.; Zhao, D.; Song, B.L.; Zhang, Z.R. Transient Receptor Potential Melastatin 4 (TRPM4) Contributes to High Salt Diet-Mediated Early-Stage Endothelial Injury. Cell Physiol. Biochem. 2017, 41, 835-848. [CrossRef]

58. Wu, M.M.; Zhai, Y.J.; Li, Y.X.; Hu, Q.Q.; Wang, Z.R.; Wei, S.P.; Zou, L.; Alli, A.A.; Thai, T.L.; Zhang, Z.R.; et al. Hydrogen peroxide suppresses TRPM4 trafficking to the apical membrane in mouse cortical collecting duct principal cells. Am. J. Physiol. Renal Physiol. 2016, 311, F1360-F1368. [CrossRef]

59. Keckeis, S.; Wernecke, L.; Salchow, D.J.; Reichhart, N.; Strauß, O. Activation of a Ca. Exp. Eye Res. 2017, 161, 61-70. [CrossRef]

60. Sakaguchi, R.; Mori, Y. Transient receptor potential (TRP) channels: Biosensors for redox environmental stimuli and cellular status. Free Radic. Biol. Med. 2020, 146, 36-44. [CrossRef]

61. Das, L.; Azmoon, P.; Banki, M.A.; Mantuano, E.; Gonias, S.L. Tissue-type plasminogen activator selectively inhibits multiple toll-like receptors in CSF-1-differentiated macrophages. PLoS ONE 2019, 14, e0224738. [CrossRef] [PubMed]

62. Gonias, S.L.; Banki, M.A.; Gilder, A.S.; Azmoon, P.; Campana, W.M.; Mantuano, E. PAI1 blocks NMDA receptor-mediated effects of tissue-type plasminogen activator on cell signaling and physiology. J. Cell Sci. 2018, 131, jcs217083. [CrossRef] [PubMed]

63. Cho, H.; Youm, J.B.; Ryu, S.Y.; Earm, Y.E.; Ho, W.K. Inhibition of acetylcholine-activated $\mathrm{K}^{+}$currents by U73122 is mediated by the inhibition of PIP(2)-channel interaction. Br. J. Pharmacol. 2001, 134, 1066-1072. [CrossRef] [PubMed]

64. Klose, A.; Huth, T.; Alzheimer, C. 1-[6-[[(17beta)-3-methoxyestra-1,3,5(10)-trien-17-yl]amino]hexyl]-1H-pyrrole-2,5-dione (U73122) selectively inhibits Kir3 and BK channels in a phospholipase C-independent fashion. Mol. Pharmacol. 2008, 74, 1203-1214. [CrossRef]

65. Sickmann, T.; Klose, A.; Huth, T.; Alzheimer, C. Unexpected suppression of neuronal G protein-activated, inwardly rectifying K ${ }^{+}$ current by common phospholipase C inhibitor. Neurosci. Lett. 2008, 436, 102-106. [CrossRef]

66. Mogami, H.; Lloyd Mills, C.; Gallacher, D.V. Phospholipase C inhibitor, U73122, releases intracellular Ca ${ }^{2+}$, potentiates Ins(1,4,5)P3mediated $\mathrm{Ca}^{2+}$ release and directly activates ion channels in mouse pancreatic acinar cells. Biochem. J. 1997, 324 Pt 2, 645-651. [CrossRef]

67. Chen, X.; Feng, L.; Yao, H.; Yang, L.; Qin, Y. Efficacy and safety of diazoxide for treating hyperinsulinemic hypoglycemia: A systematic review and meta-analysis. PLOS ONE 2021, 16, e0246463. [CrossRef]

68. Pipatpolkai, T.; Usher, S.; Stansfeld, P.J.; Ashcroft, F.M. New insights into K. Nat. Rev. Endocrinol. 2020, 16, 378-393. [CrossRef]

69. Hansen, J.B. Towards selective Kir6.2/SUR1 potassium channel openers, medicinal chemistry and therapeutic perspectives. Curr. Med. Chem. 2006, 13, 361-376. [CrossRef]

70. Guinamard, R.; Rahmati, M.; Lenfant, J.; Bois, P. Characterization of a $\mathrm{Ca}^{2+}$-activated nonselective cation channel during dedifferentiation of cultured rat ventricular cardiomyocytes. J. Membr. Biol. 2002, 188, 127-135. [CrossRef]

71. Nilius, B.; Prenen, J.; Voets, T.; Droogmans, G. Intracellular nucleotides and polyamines inhibit the $\mathrm{Ca}^{2+}$-activated cation channel TRPM4b. Pflugers Arch. 2004, 448, 70-75. [CrossRef]

72. Suh, S.H.; Watanabe, H.; Droogmans, G.; Nilius, B. ATP and nitric oxide modulate a Ca ${ }^{2+}$-activated non-selective cation current in macrovascular endothelial cells. Pflugers Arch. 2002, 444, 438-445. [CrossRef]

73. Talavera, K.; Yasumatsu, K.; Yoshida, R.; Margolskee, R.F.; Voets, T.; Ninomiya, Y.; Nilius, B. The taste transduction channel TRPM5 is a locus for bitter-sweet taste interactions. FASEB J. 2008, 22, 1343-1355. [CrossRef]

74. Grand, T.; Demion, M.; Norez, C.; Mettey, Y.; Launay, P.; Becq, F.; Bois, P.; Guinamard, R. 9-phenanthrol inhibits human TRPM4 but not TRPM5 cationic channels. Br. J. Pharmacol. 2008, 153, 1697-1705. [CrossRef]

75. Guinamard, R.; Simard, C.; Del Negro, C. Flufenamic acid as an ion channel modulator. Pharmacol. Ther. 2013, 138, $272-284$. [CrossRef]

76. Vennekens, R.; Nilius, B. Insights into TRPM4 function, regulation and physiological role. Handb. Exp. Pharmacol. 2007, 269-285. [CrossRef] 
77. Guinamard, R.; Hof, T.; Del Negro, C.A. The TRPM4 channel inhibitor 9-phenanthrol. Br. J. Pharmacol. 2014, 171, 1600-1613. [CrossRef]

78. Ozhathil, L.C.; Delalande, C.; Bianchi, B.; Nemeth, G.; Kappel, S.; Thomet, U.; Ross-Kaschitza, D.; Simonin, C.; Rubin, M.; Gertsch, J.; et al. Identification of potent and selective small molecule inhibitors of the cation channel TRPM4. Br. J. Pharmacol. 2018, 175, 2504-2519. [CrossRef]

79. Delalande, C.; Awale, M.; Rubin, M.; Probst, D.; Ozhathil, L.C.; Gertsch, J.; Abriel, H.; Reymond, J.L. Optimizing TRPM4 inhibitors in the MHFP6 chemical space. Eur. J. Med. Chem. 2019, 166, 167-177. [CrossRef]

80. Chen, B.; Gao, Y.; Wei, S.; Low, S.W.; Ng, G.; Yu, D.; Tu, T.M.; Soong, T.W.; Nilius, B.; Liao, P. TRPM4-specific blocking antibody attenuates reperfusion injury in a rat model of stroke. Pflugers Arch. 2019, 471, 1455-1466. [CrossRef]

81. Low, S.W.; Gao, Y.; Wei, S.; Chen, B.; Nilius, B.; Liao, P. Development and characterization of a monoclonal antibody blocking human TRPM4 channel. Sci. Rep. 2021, 11, 10411. [CrossRef] [PubMed]

82. Chen, B.; Ng, G.; Gao, Y.; Low, S.W.; Sandanaraj, E.; Ramasamy, B.; Sekar, S.; Bhakoo, K.; Soong, T.W.; Nilius, B.; et al. Non-Invasive Multimodality Imaging Directly Shows TRPM4 Inhibition Ameliorates Stroke Reperfusion Injury. Transl. Stroke Res. 2019, 10, 91-103. [CrossRef] [PubMed]

83. Balla, T. Pharmacology of phosphoinositides, regulators of multiple cellular functions. Curr. Pharm. Des. 2001, 7, 475-507. [CrossRef] [PubMed]

84. Nichols, C.G. KATP channels as molecular sensors of cellular metabolism. Nature 2006, 440, 470-476. [CrossRef]

85. Liman, E.R. Regulation by voltage and adenine nucleotides of a $\mathrm{Ca}^{2+}$-activated cation channel from hamster vomeronasal sensory neurons. J. Physiol. 2003, 548, 777-787. [CrossRef]

86. Guo, J.; She, J.; Zeng, W.; Chen, Q.; Bai, X.C.; Jiang, Y. Structures of the calcium-activated, non-selective cation channel TRPM4 Nature 2017, 552, 205-209. [CrossRef]

87. Chen, M.; Simard, J.M. Cell swelling and a nonselective cation channel regulated by internal $\mathrm{Ca}^{2+}$ and ATP in native reactive astrocytes from adult rat brain. J. Neurosci. 2001, 21, 6512-6521. [CrossRef]

88. Ali, S.; Solano, A.S.; Gonzales, A.L.; Thakore, P.; Krishnan, V.; Yamasaki, E.; Earley, S. Nitric Oxide Signals Through IRAG to Inhibit TRPM4 Channels and Dilate Cerebral Arteries. Function 2021, 2, zqab051. [CrossRef]

89. Krippeit-Drews, P.; Kröncke, K.D.; Welker, S.; Zempel, G.; Roenfeldt, M.; Ammon, H.P.; Lang, F.; Drews, G. The effects of nitric oxide on the membrane potential and ionic currents of mouse pancreatic B cells. Endocrinology 1995, 136, 5363-5369. [CrossRef]

90. Miyoshi, H.; Nakaya, Y.; Moritoki, H. Nonendothelial-derived nitric oxide activates the ATP-sensitive $\mathrm{K}^{+}$channel of vascular smooth muscle cells. FEBS Lett. 1994, 345, 47-49. [CrossRef]

91. Choi, Y.B.; Tenneti, L.; Le, D.A.; Ortiz, J.; Bai, G.; Chen, H.S.; Lipton, S.A. Molecular basis of NMDA receptor-coupled ion channel modulation by S-nitrosylation. Nat. Neurosci. 2000, 3, 15-21. [CrossRef]

92. Matsumoto, S.; Takahashi, T.; Ikeda, M.; Nishikawa, T.; Yoshida, S.; Kawase, T. Effects of N(G)-monomethyl-L-arginine on Ca ${ }^{2+}$ current and nitric-oxide synthase in rat ventricular myocytes. J. Pharmacol. Exp. Ther. 2000, 294, 216-223.

93. Koh, S.D.; Campbell, J.D.; Carl, A.; Sanders, K.M. Nitric oxide activates multiple potassium channels in canine colonic smooth muscle. J. Physiol. 1995, 489 Pt 3, 735-743. [CrossRef]

94. Pegg, A.E. Functions of Polyamines in Mammals. J. Biol. Chem. 2016, 291, 14904-14912. [CrossRef]

95. Lopatin, A.N.; Nichols, C.G. $\mathrm{K}^{+}$dependence of polyamine-induced rectification in inward rectifier potassium channels (IRK1, Kir2.1). J. Gen. Physiol. 1996, 108, 105-113. [CrossRef]

96. Mott, D.D.; Washburn, M.S.; Zhang, S.; Dingledine, R.J. Subunit-dependent modulation of kainate receptors by extracellular protons and polyamines. J. Neurosci. 2003, 23, 1179-1188. [CrossRef]

97. Washburn, M.S.; Dingledine, R. Block of alpha-amino-3-hydroxy-5-methyl-4-isoxazolepropionic acid (AMPA) receptors by polyamines and polyamine toxins. J. Pharmacol. Exp. Ther. 1996, 278, 669-678.

98. Kerschbaum, H.H.; Kozak, J.A.; Cahalan, M.D. Polyvalent cations as permeant probes of MIC and TRPM7 pores. Biophys. J. 2003, 84, 2293-2305. [CrossRef]

99. Chubanov, V.; Mederos y Schnitzler, M.; Meißner, M.; Schäfer, S.; Abstiens, K.; Hofmann, T.; Gudermann, T. Natural and synthetic modulators of SK $(\mathrm{K}(\mathrm{ca}) 2)$ potassium channels inhibit magnesium-dependent activity of the kinase-coupled cation channel TRPM7. Br. J. Pharmacol. 2012, 166, 1357-1376. [CrossRef]

100. Marivingt-Mounir, C.; Norez, C.; Dérand, R.; Bulteau-Pignoux, L.; Nguyen-Huy, D.; Viossat, B.; Morgant, G.; Becq, F.; Vierfond, J.M.; Mettey, Y. Synthesis, SAR, crystal structure, and biological evaluation of benzoquinoliziniums as activators of wild-type and mutant cystic fibrosis transmembrane conductance regulator channels. J. Med. Chem. 2004, 47, 962-972. [CrossRef]

101. Norez, C.; Bilan, F.; Kitzis, A.; Mettey, Y.; Becq, F. Proteasome-dependent pharmacological rescue of cystic fibrosis transmembrane conductance regulator revealed by mutation of glycine 622. J. Pharmacol. Exp. Ther. 2008, 325, 89-99. [CrossRef] [PubMed]

102. Woodward, R.M.; Polenzani, L.; Miledi, R. Effects of fenamates and other nonsteroidal anti-inflammatory drugs on rat brain GABAA receptors expressed in Xenopus oocytes. J. Pharmacol. Exp. Ther. 1994, 268, 806-817. [PubMed]

103. Liantonio, A.; Giannuzzi, V.; Picollo, A.; Babini, E.; Pusch, M.; Conte Camerino, D. Niflumic acid inhibits chloride conductance of rat skeletal muscle by directly inhibiting the CLC-1 channel and by increasing intracellular calcium. Br. J. Pharmacol. 2007, 150, 235-247. [CrossRef] [PubMed]

104. Amarouch, M.Y.; Syam, N.; Abriel, H. Biochemical, single-channel, whole-cell patch clamp, and pharmacological analyses of endogenous TRPM4 channels in HEK293 cells. Neurosci. Lett. 2013, 541, 105-110. [CrossRef] [PubMed] 
105. Burt, R.; Graves, B.M.; Gao, M.; Li, C.; Williams, D.L.; Fregoso, S.P.; Hoover, D.B.; Li, Y.; Wright, G.L.; Wondergem, R. 9Phenanthrol and flufenamic acid inhibit calcium oscillations in HL-1 mouse cardiomyocytes. Cell Calcium 2013, 54, $193-201$. [CrossRef]

106. Buntschu, S.; Tscherter, A.; Heidemann, M.; Streit, J. Critical Components for Spontaneous Activity and Rhythm Generation in Spinal Cord Circuits in Culture. Front. Cell Neurosci. 2020, 14, 81. [CrossRef]

107. Yao, Y.; Xu, J.; Yu, T.; Chen, Z.; Xiao, Z.; Wang, J.; Hu, Y.; Wu, Y.; Zhu, D. Flufenamic acid inhibits secondary hemorrhage and BSCB disruption after spinal cord injury. Theranostics 2018, 8, 4181-4198. [CrossRef]

108. Malysz, J.; Maxwell, S.E.; Yarotskyy, V.; Petkov, G.V. TRPM4 channel inhibitors 9-phenanthrol and glibenclamide differentially decrease guinea pig detrusor smooth muscle whole-cell cation currents and phasic contractions. Am. J. Physiol. Cell Physiol. 2020, 318, C406-C421. [CrossRef]

109. Hernandez-Benito, M.J.; Macianskiene, R.; Sipido, K.R.; Flameng, W.; Mubagwa, K. Suppression of transient outward potassium currents in mouse ventricular myocytes by imidazole antimycotics and by glybenclamide. J. Pharmacol. Exp. Ther. 2001, 298, 598-606.

110. Melin, P.; Hosy, E.; Vivaudou, M.; Becq, F. CFTR inhibition by glibenclamide requires a positive charge in cytoplasmic loop three. Biochim. Biophys. Acta 2007, 1768, 2438-2446. [CrossRef]

111. Schaffer, P.; Pelzmann, B.; Bernhart, E.; Lang, P.; Mächler, H.; Rigler, B.; Koidl, B. The sulphonylurea glibenclamide inhibits voltage dependent potassium currents in human atrial and ventricular myocytes. Br. J. Pharmacol. 1999, 128, 1175-1180. [CrossRef]

112. Jiang, B.; Zhang, Y.; Wang, Y.; Li, Z.; Chen, Q.; Tang, J.; Zhu, G. Glibenclamide Attenuates Neuroinflammation and Promotes Neurological Recovery After Intracerebral Hemorrhage in Aged Rats. Front. Aging Neurosci. 2021, 13, 729652. [CrossRef]

113. Takahashi, K.; Sakamoto, K.; Kimura, J. Hypoxic stress induces transient receptor potential melastatin 2 (TRPM2) channel expression in adult rat cardiac fibroblasts. J. Pharmacol. Sci. 2012, 118, 186-197. [CrossRef]

114. Hill, K.; McNulty, S.; Randall, A.D. Inhibition of TRPM2 channels by the antifungal agents clotrimazole and econazole. Naunyn Schmiedebergs Arch. Pharmacol. 2004, 370, 227-237. [CrossRef]

115. Jensen, B.S.; Strobaek, D.; Christophersen, P.; Jorgensen, T.D.; Hansen, C.; Silahtaroglu, A.; Olesen, S.P.; Ahring, P.K. Characterization of the cloned human intermediate-conductance $\mathrm{Ca}^{2+}$-activated $\mathrm{K}^{+}$channel. Am. J. Physiol. 1998, 275, C848-C856. [CrossRef]

116. Thomas, G.P.; Karmazyn, M.; Zygmunt, A.C.; Antzelevitch, C.; Narayanan, N. The antifungal antibiotic clotrimazole potently inhibits L-type calcium current in guinea-pig ventricular myocytes. Br. J. Pharmacol. 1999, 126, 1531-1533. [CrossRef]

117. Fearon, I.M.; Ball, S.G.; Peers, C. Clotrimazole inhibits the recombinant human cardiac L-type $\mathrm{Ca}^{2+}$ channel alpha $1 \mathrm{C}$ subunit. Br. J. Pharmacol. 2000, 129, 547-554. [CrossRef]

118. Gögelein, H.; Pfannmüller, B. The nonselective cation channel in the basolateral membrane of rat exocrine pancreas. Inhibition by 3',5-dichlorodiphenylamine-2-carboxylic acid (DCDPC) and activation by stilbene disulfonates. Pflugers Arch. 1989, 413, 287-298. [CrossRef]

119. Van den Abbeele, T.; Tran Ba Huy, P.; Teulon, J. A calcium-activated nonselective cationic channel in the basolateral membrane of outer hair cells of the guinea-pig cochlea. Pflugers Arch. 1994, 427, 56-63. [CrossRef]

120. Chraibi, A.; Van den Abbeele, T.; Guinamard, R.; Teulon, J. A ubiquitous non-selective cation channel in the mouse renal tubule with variable sensitivity to calcium. Pflugers Arch. 1994, 429, 90-97. [CrossRef]

121. Tran, T.D.; Zolochevska, O.; Figueiredo, M.L.; Wang, H.; Yang, L.J.; Gimble, J.M.; Yao, S.; Cheng, H. Histamine-induced Ca ${ }^{2+}$ signalling is mediated by TRPM4 channels in human adipose-derived stem cells. Biochem. J. 2014, 463, 123-134. [CrossRef]

122. Simard, C.; Sallé, L.; Rouet, R.; Guinamard, R. Transient receptor potential melastatin 4 inhibitor 9-phenanthrol abolishes arrhythmias induced by hypoxia and re-oxygenation in mouse ventricle. Br. J. Pharmacol. 2012, 165, 2354-2364. [CrossRef]

123. Simard, C.; Hof, T.; Keddache, Z.; Launay, P.; Guinamard, R. The TRPM4 non-selective cation channel contributes to the mammalian atrial action potential. J. Mol. Cell Cardiol. 2013, 59, 11-19. [CrossRef]

124. Gonzales, A.L.; Garcia, Z.I.; Amberg, G.C.; Earley, S. Pharmacological inhibition of TRPM4 hyperpolarizes vascular smooth muscle. Am. J. Physiol. Cell Physiol. 2010, 299, C1195-C1202. [CrossRef]

125. Wang, B.H.; Ternai, B.; Polya, G.M. Specific inhibition of cyclic AMP-dependent protein kinase by the antimalarial halofantrine and by related phenanthrenes. Biol. Chem. Hoppe Seyler 1994, 375, 527-535. [CrossRef] [PubMed]

126. Veress, R.; Baranyai, D.; Hegyi, B.; Kistamás, K.; Dienes, C.; Magyar, J.; Bányász, T.; Nánási, P.P.; Szentandrássy, N.; Horváth, B Transient receptor potential melastatin 4 channel inhibitor 9-phenanthrol inhibits K. Can. J. Physiol. Pharmacol. 2018, 96, 1022-1029. [CrossRef] [PubMed]

127. Hou, J.W.; Fei, Y.D.; Li, W.; Chen, Y.H.; Wang, Q.; Xiao, Y.; Wang, Y.P.; Li, Y.G. The transient receptor potential melastatin 4 channel inhibitor 9-phenanthrol modulates cardiac sodium channel. Br. J. Pharmacol. 2018, 175, 4325-4337. [CrossRef] [PubMed]

128. Garland, C.J.; Smirnov, S.V.; Bagher, P.; Lim, C.S.; Huang, C.Y.; Mitchell, R.; Stanley, C.; Pinkney, A.; Dora, K.A. TRPM4 inhibitor 9-phenanthrol activates endothelial cell intermediate conductance calcium-activated potassium channels in rat isolated mesenteric artery. Br. J. Pharmacol. 2015, 172, 1114-1123. [CrossRef]

129. Burris, S.K.; Wang, Q.; Bulley, S.; Neeb, Z.P.; Jaggar, J.H. 9-Phenanthrol inhibits recombinant and arterial myocyte TMEM16A channels. Br. J. Pharmacol. 2015, 172, 2459-2468. [CrossRef]

130. Arullampalam, P.; Preti, B.; Ross-Kaschitza, D.; Lochner, M.; Rougier, J.S.; Abriel, H. Species-Specific Effects of Cation Channel TRPM4 Small-Molecule Inhibitors. Front. Pharmacol. 2021, 12, 712354. [CrossRef] 
131. Dienes, C.; Hézső, T.; Kiss, D.Z.; Baranyai, D.; Kovács, Z.M.; Szabó, L.; Magyar, J.; Bányász, T.; Nánási, P.P.; Horváth, B.; et al. Electrophysiological Effects of the Transient Receptor Potential Melastatin 4 Channel Inhibitor (4-Chloro-2-(2chlorophenoxy)acetamido) Benzoic Acid (CBA) in Canine Left Ventricular Cardiomyocytes. Int. J. Mol. Sci 2021, $22,9499$. [CrossRef]

132. Borgström, A.; Hauert, B.; Kappel, S.; Zoni, E.; Kiener, M.; Stokłosa, P.; Baur, R.; Spahn, M.; Kruithof-de Julio, M.; Peinelt, C. Small Molecular Inhibitors Block TRPM4 Currents in Prostate Cancer Cells, with Limited Impact on Cancer Hallmark Functions. J. Mol. Biol. 2020, 433, 166665. [CrossRef]

133. Stokłosa, P.; Borgström, A.; Hauert, B.; Baur, R.; Peinelt, C. Investigation of Novel Small Molecular TRPM4 Inhibitors in Colorectal Cancer Cells. Cancers 2021, 13, 5400. [CrossRef]

134. Bianchi, B.; Smith, P.A.; Abriel, H. The ion channel TRPM4 in murine experimental autoimmune encephalomyelitis and in a model of glutamate-induced neuronal degeneration. Mol. Brain 2018, 11, 41. [CrossRef]

135. Li, K.; Abbott, S.B.G.; Shi, Y.; Eggan, P.; Gonye, E.C.; Bayliss, D.A. TRPM4 mediates a subthreshold membrane potential oscillation in respiratory chemoreceptor neurons that drives pacemaker firing and breathing. Cell Rep. 2021, 34, 108714. [CrossRef]

136. Wei, S.; Low, S.W.; Poore, C.P.; Chen, B.; Gao, Y.; Nilius, B.; Liao, P. Comparison of Anti-oncotic Effect of TRPM4 Blocking Antibody in Neuron, Astrocyte and Vascular Endothelial Cell Under Hypoxia. Front. Cell Dev. Biol. 2020, 8, 562584. [CrossRef]

137. Fire, A.; Xu, S.; Montgomery, M.K.; Kostas, S.A.; Driver, S.E.; Mello, C.C. Potent and specific genetic interference by doublestranded RNA in Caenorhabditis elegans. Nature 1998, 391, 806-811. [CrossRef]

138. Gönczi, M.; Szentandrássy, N.; Johnson, I.T.; Heagerty, A.M.; Weston, A.H. Investigation of the role of TASK-2 channels in rat pulmonary arteries; pharmacological and functional studies following RNA interference procedures. Br. J. Pharmacol. 2006, 147, 496-505. [CrossRef]

139. Gonzales, A.L.; Amberg, G.C.; Earley, S. $\mathrm{Ca}^{2+}$ release from the sarcoplasmic reticulum is required for sustained TRPM4 activity in cerebral artery smooth muscle cells. Am. J. Physiol. Cell Physiol. 2010, 299, C279-C288. [CrossRef]

140. Becerra, A.; Echeverría, C.; Varela, D.; Sarmiento, D.; Armisén, R.; Nuñez-Villena, F.; Montecinos, M.; Simon, F. Transient receptor potential melastatin 4 inhibition prevents lipopolysaccharide-induced endothelial cell death. Cardiovasc. Res. 2011, 91, 677-684. [CrossRef]

141. Loh, K.P.; Ng, G.; Yu, C.Y.; Fhu, C.K.; Yu, D.; Vennekens, R.; Nilius, B.; Soong, T.W.; Liao, P. TRPM4 inhibition promotes angiogenesis after ischemic stroke. Pflugers Arch. 2014, 466, 563-576. [CrossRef] [PubMed]

142. Hazalin, N.A.M.N.; Liao, P.; Hassan, Z. TRPM4 inhibition improves spatial memory impairment and hippocampal long-term potentiation deficit in chronic cerebral hypoperfused rats. Behav. Brain Res. 2020, 393, 112781. [CrossRef] [PubMed]

143. Kim, E.C.; Choi, S.K.; Lim, M.; Yeon, S.I.; Lee, Y.H. Role of endogenous ENaC and TRP channels in the myogenic response of rat posterior cerebral arteries. PLoS ONE 2013, 8, e84194. [CrossRef] [PubMed]

144. Holzmann, C.; Kappel, S.; Kilch, T.; Jochum, M.M.; Urban, S.K.; Jung, V.; Stöckle, M.; Rother, K.; Greiner, M.; Peinelt, C. Transient receptor potential melastatin 4 channel contributes to migration of androgen-insensitive prostate cancer cells. Oncotarget 2015, 6 , 41783-41793. [CrossRef] [PubMed]

145. Yu, C.X.; Zhang, Y.Y.; Wu, X.Y.; Tang, H.X.; Liang, X.Q.; Xue, Z.M.; Xue, Y.D.; Li, J.; Zhu, H.; Huo, R.; et al. Transient receptor potential melastatin 4 contributes to early-stage endothelial injury induced by arsenic trioxide. Toxicol. Lett. 2019, 312, 98-108. [CrossRef]

146. Wang, F.; Wu, P.; Gong, S.; Chen, Y.; Gao, J.; Wang, S.; Shen, Q.; Tao, H.; Hua, F.; Zhou, Z.; et al. Aberrant TRPM4 expression in MLL-rearranged acute myeloid leukemia and its blockade induces cell cycle arrest via AKT/GLI1/Cyclin D1 pathway. Cell Signal. 2020, 72, 109643. [CrossRef]

147. Launay, P.; Cheng, H.; Srivatsan, S.; Penner, R.; Fleig, A.; Kinet, J.P. TRPM4 regulates calcium oscillations after T cell activation. Science 2004, 306, 1374-1377. [CrossRef]

148. Nilius, B.; Prenen, J.; Janssens, A.; Owsianik, G.; Wang, C.; Zhu, M.X.; Voets, T. The selectivity filter of the cation channel TRPM4 J. Biol. Chem. 2005, 280, 22899-22906. [CrossRef]

149. Marigo, V.; Courville, K.; Hsu, W.H.; Feng, J.M.; Cheng, H. TRPM4 impacts on $\mathrm{Ca}^{2+}$ signals during agonist-induced insulin secretion in pancreatic beta-cells. Mol. Cell Endocrinol. 2009, 299, 194-203. [CrossRef] 